\title{
Early-Life Exposure to Environmental Air Pollution and Autism Spectrum Disorder: A Review of Available Evidence
}

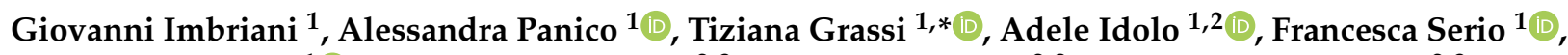 \\ Francesco Bagordo 1® , Giovanni De Filippis 2,3, Donato De Giorgi 2,3, Gianfranco Antonucci 2,3, \\ Prisco Piscitelli ${ }^{2,3}{ }^{(\mathbb{D}}$, Manuela Colangelo ${ }^{4}$, Luigi Peccarisi ${ }^{2,3}$, Maria Rosaria Tumolo ${ }^{5,6}$, Roberto De Masi ${ }^{2,7}$ (D), \\ Alessandro Miani ${ }^{8,9}$ and Antonella De Donno ${ }^{1}$ (D)
}

check for updates

Citation: Imbriani, G.; Panico, A.; Grassi, T.; Idolo, A.; Serio, F.; Bagordo, F.; De Filippis, G.; De Giorgi, D.; Antonucci, G.; Piscitelli, P.; et al. Early-Life Exposure to Environmental Air Pollution and Autism Spectrum Disorder: A Review of Available Evidence. Int. J. Environ. Res. Public Health 2021, 18, 1204. https:// doi.org/10.3390/ijerph18031204

Academic Editor: Paul B. Tchounwou Received: 17 November 2020

Accepted: 26 January 2021

Published: 29 January 202

Publisher's Note: MDPI stays neutral with regard to jurisdictional claims in published maps and institutional affiliations.

Copyright: (C) 2021 by the authors. Licensee MDPI, Basel, Switzerland. This article is an open access article distributed under the terms and conditions of the Creative Commons Attribution (CC BY) license (https:// creativecommons.org/licenses/by/ $4.0 /)$.
1 Department of Biological and Environmental Sciences and Technology, University of Salento, via Monteroni 165, 73100 Lecce, Italy; giovanni.imbriani@unisalento.it (G.I.); alessandra.panico@unisalento.it (A.P.); adele.idolo@unisalento.it (A.I.); francesca.serio@unisalento.it (F.S.); francesco.bagordo@unisalento.it (F.B.); antonella.dedonno@unisalento.it (A.D.D.)

2 Local Health Authority ASL Le, 73100 Lecce, Italy; giov.defilippis@gmail.com (G.D.F.); donatodg@libero.it (D.D.G.); antongian2011@libero.it (G.A.); priscofreedom@hotmail.com (P.P.); ginopeccarisi@libero.it (L.P.); dmsrrt@gmail.com (R.D.M.)

3 Medical Professional Association (OMCEO), 73100 Lecce, Italy

4 Italian Association of Health, Environment and Society (AISAS), via De Gasperi 22, Lizzanello, 73023 Lecce, Italy; manuela.colangelo95@gmail.com

5 Research Unit of Brindisi, c/o ex Osp. Di Summa, Institute for Research on Population and Social Policies, National Research Council, Piazza Di Summa, 72100 Brindisi, Italy; mariarosaria.tumolo@irpps.cnr.it

6 c/o Campus Ecotekne via Monteroni, Branch of Lecce, Institute of Clinical Physiology, National Research Council, 73100 Lecce, Italy

7 Multiple Sclerosis Centre, Laboratory of Neuroproteomics, "Francesco Ferrari" Hospital, 73042 Casarano, Italy

8 Italian Society of Environmental Medicine, 02100 Milan, Italy; alessandro.miani@gmail.com

9 Department of Environmental Science and Policy, University of Milan, 02100 Milan, Italy

* Correspondence: tiziana.grassi@unisalento.it

Abstract: The number of children diagnosed with Autism Spectrum Disorder (ASD) has rapidly increased globally. Genetic and environmental factors both contribute to the development of ASD Several studies showed linkage between prenatal, early postnatal air pollution exposure and the risk of developing ASD. We reviewed the available literature concerning the relationship between early-life exposure to air pollutants and ASD onset in childhood. We searched on Medline and Scopus for cohort or case-control studies published in English from 1977 to 2020. A total of 20 articles were selected for the review. We found a strong association between maternal exposure to particulate matter (PM) during pregnancy or in the first years of the children's life and the risk of the ASD. This association was found to be stronger with $\mathrm{PM}_{2.5}$ and less evident with the other pollutants. Current evidence suggest that pregnancy is the period in which exposure to environmental pollutants seems to be most impactful concerning the onset of ASD in children. Air pollution should be considered among the emerging risk factors for ASD. Further epidemiological and toxicological studies should address molecular pathways involved in the development of ASD and determine specific cause-effect associations.

Keywords: autism spectrum disorder; environmental air pollution; early life exposure; pregnancy

\section{Introduction}

Autism Spectrum Disorder (ASD) can be defined as a set of heterogeneous conditions of neurological development characterized by early difficulties in social communication and unusual repetitive behaviors along with limited interests, some of which can be attributed to several etiological factors including Mendelian mutations of individual genes or resulting from complex interactions between genetic and non-genetic risk factors [1]. 
The most recent American data from the US Centers for Disease Control and Prevention (CDC), regarding year 2016, report a prevalence of ASD up to 1 child out of 54 in pediatric population aged 8 years old [2]. The overall prevalence of ASD has grown exponentially since 2000, passing from 1 case out of 150 new births (in children born in 1992) to 1 case out of 59 in 2014, concerning children born in $2006[3,4]$.

According to the World Health Organization (WHO), 1 in 160 children suffer from ASD [5]. This estimate represents an average figure obtained by analyzing several studies produced globally. Epidemiological studies carried out over the past 50 years seem to show a constant increase in prevalence rates. There are many possible explanations for this rapid increase, including better awareness, expansion of diagnostic criteria [6], better diagnostic tools, and better reporting $[7,8]$; but all these conditions cannot explain the huge expansion of the overall number of ASD subjects.

At the basis of its complex etiology, there is a genetic component that has been confirmed over the years by the identification of mutations of several high-confidence genes involved in the neuronal and cortical organization, in the formation and maturation of synapses, and in neurotransmission [9-12], that can lead to a transient interruption in the brain's development process [13].

In an epigenetic perspective, environmental factors have recently emerged as extremely important contributors to the etiology and pathophysiology of ASD, so that a better understanding of these gene-environment interactions is now fundamental [14].

Air pollution is one of the most studied environmental factors which seems to play an important role in the etiology of ASD. Several studies have identified in recent years a positive association between exposure to different environmental pollutants-such as atmospheric particulate matter $\left(\mathrm{PM}_{2.5}\right.$ and $\left.\mathrm{PM}_{10}\right)$, nitrogen dioxide $\left(\mathrm{NO}_{2}\right)$, sulfur dioxide $\left(\mathrm{SO}_{2}\right)$, carbon monoxide $(\mathrm{CO})$, and ozone $\left(\mathrm{O}_{3}\right)[15]$ - and the onset of neurodevelopmental diseases, including ASD [16]. The neurotoxicity mechanisms of these pollutants have not been fully understood. However, inflammation and oxidative stress processes seem to play a crucial role in the structural and functional changes affecting the central nervous system (CNS) that may cause mental disorders $[17,18]$, possibly mediated by epigenetics modifications of the genes involved in these processes [19].

Another key concept for understanding causation of ASD concerns the "critical time window", as symptoms commonly appear in the early years of the baby's life, thus suggesting a strong probability of origin during the preconceptional, pregnancy, and early stages of life [14]. Studies on human pregnancy and in the early years of life found that prenatal exposure to air pollution during the development and maturation phase of the CNS can be linked to a systemic inflammatory response, which consequently causes an impairment in the neurodevelopment process [20]. Therefore, we aimed at carrying out a comprehensive review of potential associations between regularly monitored air pollutants and ASD, and, at same time, analyzing the potential factors that could influence this relationship (i.e., "exposure window" and the different covariates that are considered in scientific literature). The results obtained on the basis of the scientific evidence reported in the literature could provide more detailed and reliable information on the possible interaction between air pollutants and ASD, which could help epidemiologists and other researchers to carry out further studies to investigate this potential association.

\section{Materials and Methods}

We reviewed the available literature concerning the relationship between early-life exposure to air pollutants and ASD onset in childhood. The potential factors that could influence this relationship, such as "exposure window" and the different covariates are displayed in scientific literature. The review was carried out according to the main items reported in the PRISMA checklist 2009 [21]. We searched on Medline and Scopus for cohort or case-control studies published from 1977 to 2020, by using the following keywords: "autism spectrum disorder" AND "air pollution" OR "particulate matter" OR "environmental pollutants" OR "polycyclic aromatic hydrocarbons" OR "nitrogen dioxide" OR 
"PM2.5" OR "PM10" OR “traffic-related pollutants" AND "prenatal" OR "pregnancy" OR "early life".

The bibliographic search was carried out separately in each database by selecting the studies based on their titles or abstracts and subsequently, the entire articles were analyzed. Studies were considered for the review according to specific inclusion criteria:

- human studies;

- full-text articles in English;

- assessment of exposure to airborne environmental pollutants during pregnancy or in the first years of the baby's life;

- only case-control studies or cohort studies.

For each examined study, we extrapolated the following information:

- authors and year;

- study design;

- sample size;

- exposure assessment measures;

- method of analysis;

- adjustment variables;

- $\quad$ ASD outcome assessment;

- $\quad$ time window of exposure;

- main findings.

A total of 20 articles were selected for the review. Exploration of heterogeneity of the studies was performed by assessing their quality (i.e., level of evidence). Interpretation of the findings was conducted in the frame of current knowledge [22].

\section{Results}

We retrieved a total of 575 references from our literature search, of which 54 met inclusion criteria based on title and abstract screening and 20 further met inclusion criteria based on full text screening (Figure 1).
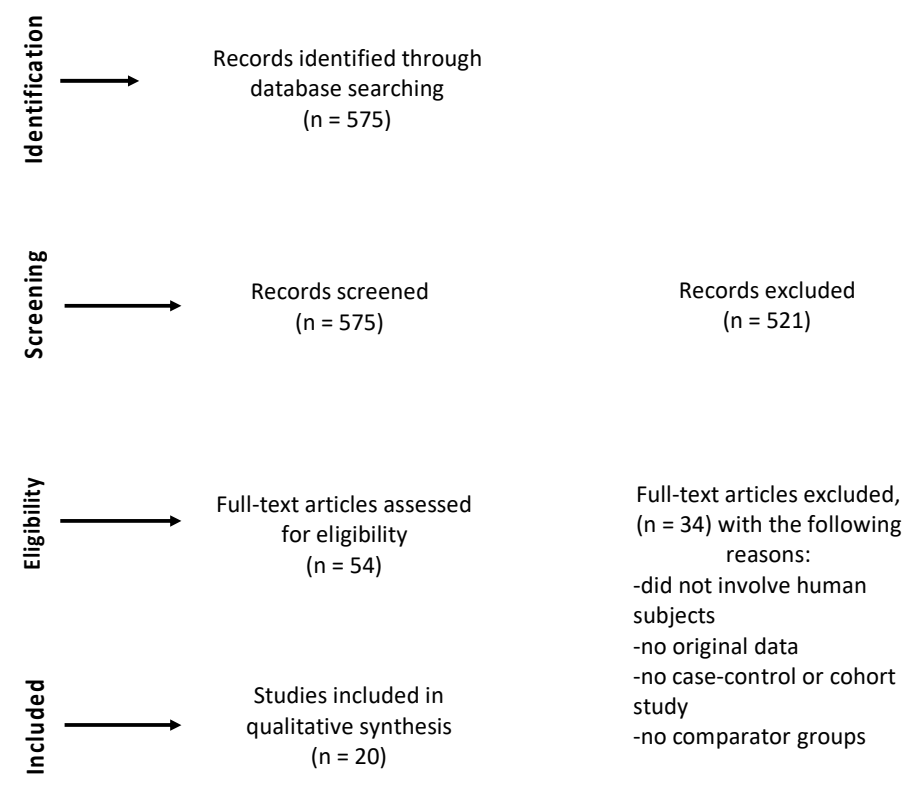

Figure 1. Flow diagram.

\subsection{Association between PM and ASD}

We found 12 studies (9 case-control and 3 cohort studies) investigating the association between the risk of ASD onset and maternal exposure to PM $\left(\mathrm{PM}_{2.5}\right.$ and $\left.\mathrm{PM}_{10}\right)$ during pregnancy and in the first years of the child's life and the risk ASD onset (Table 1). The 
case-control studies showed a positive association between PM exposure (especially $\mathrm{PM}_{2.5}$ ) during pregnancy or early life and ASD [23-31], while the cohort studies demonstrated a less significant relationship.

A recent study involving 674 children with ASD and 855 controls recruited in the Study to Explore Early Development carried out in the United States found a positive association between exposure to $\mathrm{PM}_{2.5}$ in children's first year of life and ASD. The exposure to $\mathrm{PM}_{2.5}$ in the different periods ranging from three months before pregnancy, the three trimesters of pregnancy and the first year of life, was assessed using a satellite-based model. The strongest association was found between $\mathrm{PM}_{2.5}$ in the first year of life, with an odds ratio (OR) of $1.3(95 \% \mathrm{CI}: 1.0,1.6)$ for $1.6 \mu \mathrm{g} / \mathrm{m}^{3}$ increase in $\mathrm{PM}_{2.5}$ [23].

The same population was analyzed in another study carried out in 2019 to assess the effects of the exposure to $\mathrm{PM}_{2.5}$ generated nearby roadways during the three trimesters of pregnancy and during the first year of life of the children. In this study, the deprivation index was also assessed as indicator of socio-economic status of the examined population. The association between exposure to $\mathrm{PM}_{2.5}$ and the risk of ASD in the first year of life was found stronger among those presenting a higher deprivation state $(\mathrm{OR}=2.42,95 \% \mathrm{CI}=1.20,4.86)$ than those living in a low deprivation state $(\mathrm{OR}=1.46,95 \% \mathrm{CI}=0.80,2.65)$ [24].

A recent study published in 2019 assessed the association between ASD and $\mathrm{PM}_{2.5}$ during the three trimesters of pregnancy and in the first two years of life, identifying a correlation between ASD and the increase in $\mathrm{PM}_{2.5}$ concentrations. The study was conducted on a group of 428 cases and 6420 controls in Ohio and used the daily $\mathrm{PM}_{2.5}$ individual exposure estimations provided by the United States Environmental Protection Agency (US EPA), based on their residential address. The analysis showed that the ORs related to second trimester, the first year of life and the cumulative period (that included the period from pregnancy to the second year of life) were: 1.41 (95\%CI: $0.89,2.24), 1.54$ (95\%CI: 0.98, 2.40), 1.52 (95\%CI: 1.00, 2.31), respectively [25].

A study conducted on the Danish population that enrolled 15,387 children with ASD and 68,139 controls, examined exposure to various environmental pollutants, during the 9 months of pregnancy and in the following 9 months of life using estimates provided by the dispersion models (AirGIS) for the detected pollutants $\left(\mathrm{NO}_{2}, \mathrm{SO}_{2}, \mathrm{PM}_{2.5}\right.$, and $\left.\mathrm{PM}_{10}\right)$ in relation to the maternal residence during the examined periods. The data obtained showed that exposure to $\mathrm{PM}_{2.5}$ and $\mathrm{PM}_{10}$ during the 9 months after pregnancy increased the risk of a diagnosis of ASD; in particular, the adjusted ORs for $\mathrm{PM}_{2.5}$ was of 1.06 (95\%CI: 1.01, 1.11) per interquartile range (IQR) increased by $3.61 \mu \mathrm{g} / \mathrm{m}^{3}$, while an OR of 1.04 (95\%CI: 1.01, 1.15) per each increase of $3.8 \mu \mathrm{g} / \mathrm{m}^{3}$ in IQR value was observed for $\mathrm{PM}_{10}$ [26].

A case-control study developed in Shanghai that enrolled 124 cases and 1240 controls assessed the relationship between exposure to $\mathrm{PM}_{2.5}$ and $\mathrm{PM}_{10}$ during the first three years of life and the risk of developing ASD. Using satellite data to evaluate the median levels of PM and performing a logistic regression model to evaluate the association between $\mathrm{PM}_{2.5}, \mathrm{PM}_{10}$ and ASD, the researchers observed that there was a strong association. In particular, for $\mathrm{PM}_{2.5}$ they calculated an OR of 1.50 (95\%CI: 1.01, 2.22) in the second year of life and an OR of 1.78 (95\%CI: $1.05,3.02)$ in the third year, respectively for each increase of $3.4 \mu \mathrm{g} / \mathrm{m}^{3}$ in the IQR. As far as $\mathrm{PM}_{10}$, a clear association with ASD during the first three years of life was also found [27].

A 2015 case-control study involving 245 ASD cases and 1522 controls recruited from the Nurses' Health Study II (NHS II) study - whose mothers lived at the same address before and after the pregnancy-found that higher exposure to $\mathrm{PM}_{2.5}$ during pregnancy and, in particular, during the third trimester was associated with an increased risk of subsequent ASD diagnosis. Exposure to $\mathrm{PM}_{2.5}$, assessed by using a space-time model and linked to maternal residence addresses, showed an OR of 1.42 (95\%CI: 1.09, 1.86) per each increase of $4.40 \mu \mathrm{g} / \mathrm{m}^{3}$ in IQR value during the third quarter. This association was weaker during the first two quarters (ORs $=1.06$ and 1.00). On the contrary, no significant association was found for $\mathrm{PM}_{10}$ [28].

Another study involving 217 cases and 226 controls in southwestern Pennsylvania evaluated the association between prenatal and early life exposure to $\mathrm{PM}_{2.5}$ and the risk 
of ASD. The results showed that both prenatal exposures and those occurred in the first two years of life were associated with an increased risk of ASD, expressed by an OR of 1.51 (95\%CI: 1.10, 2.26) [29].

In 2013, a study involving 7603 children diagnosed with ASD, born in Los Angeles (California) from 1998 to 2009, and a high sample of paired controls with a ratio of 1:10, specifically assessed the influence of exposure to environmental pollutants from vehicular traffic during pregnancy on the onset of ASD. The study was performed by using a Land Use Regression (LUR) model, based on predictable pollution models, to estimate the concentrations of pollutants in a given area and correlating maternal residences to the environmental monitoring stations closest to them. The results highlighted clear associations between the onset of ASD and prenatal exposures to $\mathrm{PM}_{2.5}$ [30]. In the same year, additional analyses performed on the same population confirmed that exposure to $\mathrm{PM}_{2.5}$ during pregnancy and in the first year of life was associated with ASD. Moreover, an association between exposure to $\mathrm{PM}_{10}$ in the prenatal period and the risk of ASD was also found [31].

A 2019 retrospective cohort study that involved 246,420 children born in Kaiser Permanente Southern California (KPSC) from 1999 to 2009, assessed the risk of developing ASD associated with prenatal and first-year of life exposures to $\mathrm{PM}_{2.5}$. The results revealed a statistically significant association between the exposures to $\mathrm{PM}_{2.5}$ and the risk of ASD quantified by the following Hazard Ratios (HR) per each increase of $6.5 \mu \mathrm{g} / \mathrm{m}^{3}$ in IQR values in different phases of the pregnancy: 1.17 (95\%CI: 1.04, 1.33) in the entire ninemonths period; 1.10 (95\%CI: 1.02, 1.19) in the first trimester of pregnancy, 1.08 (95\%CI: 1.00 , $1.18)$ in the third trimester of pregnancy; 1.21 (95\%CI: 1.05, 1.40) in the first year of life [32].

At the opposite, a 2019 cohort study involving children born in Metro Vancouver, British Columbia, and Canada, born from 2004 to 2009, found no significant association between $\mathrm{PM}_{2.5}$ and ASD [33].

Another 2016 cohort study involving cohorts from four big European studies, CATSS (Sweden), Generation R (the Netherlands), GASPII (Italy), and INMA (Spain), assessed maternal exposure to $\mathrm{PM}_{2.5}$ and $\mathrm{PM}_{10}$ in the different periods of pregnancy and the risk of ASD without identifying statistically significant associations [34].

A 2015 case-control study conducted on 979 children with ASD and 14,666 controls -recruited between North Carolina and San Francisco Bay in California-assessed maternal exposure to $\mathrm{PM}_{10}$ during the three trimesters of pregnancy by interpolating (geostatistical interpolation) the daily concentrations of $\mathrm{PM}_{10}$ with a geostatistical method which considered the residence addresses of the mothers at the time of birth. The results obtained showed an association with the third trimester of pregnancy, with an OR of 1.36 (95\%CI: $1.13,1.63)$ per $10 \mu \mathrm{g} / \mathrm{m}^{3}$ increase in IQR value [35].

We also found some case-control studies which documented no significant statistical association between $\mathrm{PM}_{10}$ exposures and ASD onset. A 2018 study performed in Tehran involving 134 children with ASD and 388 controls investigated the association between long-term exposure to environmental pollutants and an increased risk of ASD diagnoses in children aged 2-10 years old. The results showed no association between the average exposure levels of mothers during pregnancy to $\mathrm{PM}_{10}$ and the onset of ASD [36].

A European study carried out on 5136 children with ASD and 18,237 controls living in Stockholm (Sweden) evaluated $\mathrm{PM}_{10}$ levels resulting from vehicular traffic by using dispersion models in relation to the addresses of maternal residence during pregnancy or the first year of the child. The results showed no association between exposures to $\mathrm{PM}_{10}$ and the risk of ASD [37].

Another study conducted on the Swedish population did not find clear associations between $\mathrm{PM}_{10}$ exposures during pregnancy, the first year of life, and the first nine years of life with ASD [38].

In the context of cohort studies, another study conducted in 2013 in Taiwan on a population of 49,073 children did not provide evidence of an association between $\mathrm{PM}_{10}$ in the first four years of life and an increased risk of ASD diagnosis [39].

Results for association between PM and ASD are shown in Table 1. 
Table 1. Studies investigating the association between exposure to particulate matter (PM) and Autism Spectrum Disorder (ASD) development.

\begin{tabular}{|c|c|c|c|c|c|c|c|c|}
\hline Authors and Year & Study Design & Sample Size/Country & $\begin{array}{l}\text { ASD Outcome } \\
\text { Assessment }\end{array}$ & Exposure Assessment & Method of Analysis & Adjustment Variables & $\begin{array}{c}\text { Time Window of } \\
\text { Exposure }\end{array}$ & Main Findings \\
\hline $\begin{array}{l}\text { McGuinn et al., } \\
2020[23]\end{array}$ & Case-control & $\begin{array}{l}674 \text { ASD cases and } 855 \\
\text { controls from } \\
\text { California, Colorado, } \\
\text { Georgia, Maryland, } \\
\text { North Carolina, and } \\
\text { Pennsylvania }\end{array}$ & $\begin{array}{l}\text { ASD case classification } \\
\text { based on the results } \\
\text { from the ADOS } \\
\text { (Autism Diagnostic } \\
\text { Observation Schedule) } \\
\text { and ADI-R (Autism } \\
\text { Diagnostic } \\
\text { Interview-Revised) }\end{array}$ & $\begin{array}{l}\text { Satellite-based model } \\
\text { to assign air pollutant } \\
\text { exposure }\left(\mathrm{PM}_{2.5}, \mathrm{O}_{3}\right) \\
\text { averages during several } \\
\text { critical periods of } \\
\text { neurodevelopment }\end{array}$ & $\begin{array}{l}\text { Logistic regression } \\
\text { model }\end{array}$ & $\begin{array}{l}\text {-study site } \\
\text {-maternal age } \\
\text {-maternal education } \\
\text {-maternal race } \\
\text {-maternal smoking, } \\
\text {-month and year of } \\
\text { birth. }\end{array}$ & $\begin{array}{l}-3 \text { months before } \\
\text { pregnancy } \\
\text {-each trimester of } \\
\text { pregnancy } \\
\text {-the entire pregnancy } \\
\text {-first year of life }\end{array}$ & $\begin{array}{l}\text { The strongest association } \\
\text { was found between } \mathrm{PM}_{2.5} \text { in } \\
\text { the first year of life, with an } \\
\text { odds ratio (OR) }=1.3 \\
(95 \% \mathrm{CI}: 1.0,1.6) \text { for } \\
1.6 \mu \mathrm{g} / \mathrm{m}^{3} \text { increase in } \mathrm{PM}_{2.5}\end{array}$ \\
\hline $\begin{array}{l}\text { Kaufman et al., } \\
2019[25]\end{array}$ & Case-control & $\begin{array}{l}428 \text { ASD cases and } 6420 \\
\text { controls from } \\
\text { metropolitan } \\
\text { Cincinnati area in } \\
\text { southwest Ohio }\end{array}$ & $\begin{array}{l}\text { ASD diagnosis } \\
\text { according to } \\
\text { International } \\
\text { Classification of } \\
\text { Diseases, Ninth } \\
\text { Revision, Clinical } \\
\text { Modification } \\
\text { (ICD-9-CM). }\end{array}$ & $\begin{array}{l}\text { Daily } \mathrm{PM}_{2.5} \text { individual } \\
\text { exposure estimations } \\
\text { provided by the United } \\
\text { States Environmental } \\
\text { Protection Agency (US } \\
\text { EPA), based on their } \\
\text { residential address }\end{array}$ & $\begin{array}{l}\text { Logistic regression } \\
\text { model }\end{array}$ & $\begin{array}{l}\text {-maternal and } \\
\text { birth-related } \\
\text { confounders } \\
\text {-multiple temporal } \\
\text { exposure windows }\end{array}$ & $\begin{array}{l}\text {-each trimester } \\
\text { pregnancy } \\
\text {-first year of life } \\
\text {-second year of life }\end{array}$ & $\begin{array}{l}\text { Odds Ratios related to } \\
\text { second trimester, the first } \\
\text { year of life and the } \\
\text { cumulative period (that } \\
\text { included the period from } \\
\text { pregnancy to the second } \\
\text { year of life) were: } 1.41 \\
(95 \% \text { CI: } 0.89,2.24), 1.54 \\
(95 \% \text { CI: } 0.98,2.40), 1.52 \\
(95 \% \text { CI: } 1.00,2.31), \\
\text { respectively }\end{array}$ \\
\hline $\begin{array}{l}\text { McGuinn et al., } \\
2019 \text { [24] }\end{array}$ & Case-control & $\begin{array}{l}674 \text { ASD cases and } 855 \\
\text { controls from } \\
\text { California, Colorado, } \\
\text { Georgia, Maryland, } \\
\text { North Carolina, and } \\
\text { Pennsylvania }\end{array}$ & $\begin{array}{l}\text { ASD case classification } \\
\text { based on the results } \\
\text { from the ADOS } \\
\text { (Autism Diagnostic } \\
\text { Observation Schedule) } \\
\text { and ADI-R (Autism } \\
\text { Diagnostic } \\
\text { Interview-Revised) }\end{array}$ & $\begin{array}{l}\text { Air pollution was } \\
\text { assessed by roadway } \\
\text { proximity and } \\
\text { particulate matter } \\
<2.5 \mu \mathrm{m}\left(\mathrm{PM}_{2.5}\right) \\
\text { exposure }\end{array}$ & $\begin{array}{l}\text { Logistic regression } \\
\text { model }\end{array}$ & $\begin{array}{l}\text {-neighborhood } \\
\text { deprivation }\end{array}$ & $\begin{array}{l}\text {-pregnancy } \\
\text {-first year of life }\end{array}$ & $\begin{array}{l}\text { The association between } \\
\text { exposure to PM } \mathrm{PM}_{2.5} \text { and the } \\
\text { risk of ASD in the first year } \\
\text { of life was found stronger } \\
\text { among those presenting a } \\
\text { higher deprivation state (OR } \\
=2.42,95 \% \mathrm{CI}=1.20,4.86 \text { ) } \\
\text { than those living in a low } \\
\text { deprivation state (OR }=1.46 \text {, } \\
95 \% \mathrm{CI}=0.80,2.65 \text { ) }\end{array}$ \\
\hline Ritz et al., 2018 [26] & Case-control & $\begin{array}{l}15,387 \text { ASD cases and } \\
68,139 \text { controls from } \\
\text { Denmark }\end{array}$ & $\begin{array}{l}\text { ASD diagnosis } \\
\text { according to } \\
\text { International } \\
\text { Classification of } \\
\text { Diseases, Tenth } \\
\text { Revision, Clinical } \\
\text { Modification } \\
\text { (ICD-10-CM) }\end{array}$ & $\begin{array}{l}\text { Exposures estimates } \\
\text { provided by the } \\
\text { dispersion models } \\
\text { (AirGIS) for the } \\
\text { detected pollutants } \\
\mathrm{NO}_{2}, \mathrm{SO}_{2}, \mathrm{PM}_{2.5} \text { and } \\
\mathrm{PM}_{10} \text { in relation to the } \\
\text { maternal residence } \\
\text { during the examined } \\
\text { periods }\end{array}$ & $\begin{array}{l}\text { Conditional logistic } \\
\text { regression }\end{array}$ & $\begin{array}{l}\text {-parental age } \\
\text {-neighborhood } \\
\text {-socio-economic } \\
\text { indicators } \\
\text {-maternal smoking }\end{array}$ & $\begin{array}{l}\text {-pregnancy } \\
-9 \text { months after } \\
\text { pregnancy }\end{array}$ & $\begin{array}{l}\text { Exposure to } \mathrm{PM}_{2.5} \text { and } \mathrm{PM}_{10} \\
\text { during the } 9 \text { months after } \\
\text { pregnancy increases the risk } \\
\text { of a diagnosis of ASD with } \\
\text { an adjusted OR of } 1.06 \\
(95 \% \mathrm{CI}: 1.01,1.11) \text { for } \\
3.61 \mu \mathrm{g} / \mathrm{m}^{3} \text { increase of } \\
\mathrm{PM}_{2.5} \text { and an OR of } 1.04 \\
(95 \% \mathrm{CI}: 1.01,1.15) \text { per each } \\
\text { increase of } 3.8 \mu \mathrm{g} / \mathrm{m}^{3} \mathrm{PM}_{10} \\
\text { in IQR value, respectively }\end{array}$ \\
\hline
\end{tabular}


Table 1. Cont.

\begin{tabular}{|c|c|c|c|c|c|c|c|c|}
\hline Authors and Year & Study Design & Sample Size/Country & $\begin{array}{l}\text { ASD Outcome } \\
\text { Assessment }\end{array}$ & Exposure Assessment & Method of Analysis & Adjustment Variables & $\begin{array}{c}\text { Time Window of } \\
\text { Exposure }\end{array}$ & Main Findings \\
\hline $\begin{array}{l}\text { Chen et al., } \\
2018 \text { [27] }\end{array}$ & Case-control & $\begin{array}{l}124 \text { ASD cases and } 1240 \\
\text { controls from China }\end{array}$ & $\begin{array}{l}\text { ASD cases were } \\
\text { diagnosed by } \\
\text { pediatricians according } \\
\text { to Diagnostic and } \\
\text { Statistical Manual of } \\
\text { Mental Disorders, 5th } \\
\text { Edition (DSM-V) }\end{array}$ & $\begin{array}{l}\text { Air pollution was } \\
\text { assessed with satellite } \\
\text { remote sensing data }\end{array}$ & $\begin{array}{l}\text { Conditional logistic } \\
\text { regression }\end{array}$ & $\begin{array}{l}\text {-birth weight } \\
\text {-gestational weeks } \\
\text {-disease history } \\
\text {-trauma history } \\
\text {-maternal age, } \\
\text {-familial mental health } \\
\text { history } \\
\text {-parents' marital status } \\
\text {-parental relationship } \\
\text {-parenting, } \\
\text {-parents' educational } \\
\text { level } \\
\text {-smoking status }\end{array}$ & $\begin{array}{l}\text {-first year of life } \\
\text {-second year of life } \\
\text {-third year of life }\end{array}$ & $\begin{array}{l}\text { Strong association with } \\
\mathrm{PM}_{2.5} \text { in the second and } \\
\text { third years of life with an } \\
\text { OR of } 1.50(1.01,2.22) \text { in the } \\
\text { second year and an OR } 1.78 \\
(1.05,3.02) \text { in the third year, } \\
\text { respectively for each } \\
\text { increase of } 3.4 \mu \mathrm{g} / \mathrm{m}^{3} \text { in the } \\
\text { IQR Strong association with } \\
\text { PM } 10 \text { during the first three } \\
\text { years of life and ASD with } \\
\text { an OR of } 1.16(0.91,1.49) \text { in } \\
\text { the first year, } 1.73(1.11,2.68) \\
\text { in the second year and } 1.58 \\
(0.98,2.56), \text { per interquartile } \\
\text { range }(\mathrm{IRR}) \text { increase per } \\
4.9 \mu \mathrm{g} / \mathrm{m}^{3}\end{array}$ \\
\hline Raz et al., 2015 [28] & Case-control & $\begin{array}{l}245 \text { ASD cases and } 1522 \\
\text { controls from United } \\
\text { States }\end{array}$ & $\begin{array}{l}\text { Final ASD case } \\
\text { classification was based } \\
\text { on the results from the } \\
\text { ADI-R Autism } \\
\text { Diagnostic } \\
\text { Interview-Revised) and } \\
\text { SRS scores (Social } \\
\text { Responsiveness Scale) }\end{array}$ & $\begin{array}{l}\text { Exposure to } \mathrm{PM}_{2.5} \text { and } \\
\mathrm{PM}_{10} \text { assessed by using } \\
\text { a space-time model and } \\
\text { linked to maternal } \\
\text { residence addresses }\end{array}$ & $\begin{array}{l}\text { Logistic regression } \\
\text { model }\end{array}$ & $\begin{array}{l}\text {-child's birth year } \\
\text {-birth month } \\
\text {-sex } \\
\text {-maternal age at birth } \\
\text {-paternal age at birth }\end{array}$ & $\begin{array}{l}-9 \text { months before } \\
\text { pregnancy } \\
\text {-trimester } 1,2,3 \\
\text {-entire pregnancy } \\
-9 \text { months after birth }\end{array}$ & $\begin{array}{l}\text { Association with } \mathrm{PM}_{2.5} \\
\text { during the third trimester of } \\
\text { pregnancy and ASD. OR of } \\
1.42(1.09,1.86) \text { per IQR } \\
\text { increase per } 4.40 \mu \mathrm{g} / \mathrm{m}^{3} \\
\text { No significant association } \\
\text { between } \mathrm{PM}_{10} \text { and ASD }\end{array}$ \\
\hline $\begin{array}{l}\text { Talbot et al., } \\
2015[29]\end{array}$ & Case-control & $\begin{array}{l}217 \text { ASD cases and } 226 \\
\text { controls from } \\
\text { southwestern } \\
\text { Pennsylvania }\end{array}$ & $\begin{array}{l}\text { A case of ASD was } \\
\text { defined as any child } \\
\text { who scored a } 15 \text { or } \\
\text { above on the Social } \\
\text { Communication } \\
\text { Questionnaire (SCQ), } \\
\text { and had written } \\
\text { documentation, } \\
\text { including the Autism } \\
\text { Diagnostic Observation } \\
\text { Schedule (ADOS) or } \\
\text { diagnosis of an ASD } \\
\text { from a child } \\
\text { psychologist or } \\
\text { psychiatrist }\end{array}$ & $\begin{array}{l}\text { Person- and time } \\
\text { specific } \mathrm{PM}_{2.5} \text { estimates } \\
\text { for individual and } \\
\text { cumulative key } \\
\text { developmental time } \\
\text { periods }\end{array}$ & $\begin{array}{l}\text { Logistic regression } \\
\text { model }\end{array}$ & $\begin{array}{l}\text {-college education } \\
\text {-smoking status } \\
\text {-race } \\
\text {-maternal age }\end{array}$ & $\begin{array}{l}\text {-pre-pregnancy } \\
\text {-each trimester, } \\
\text { pregnancy } \\
\text {-first year of life } \\
\text {-second year of life } \\
\text {-cumulative (tarting } \\
\text { from pre-pregnancy) }\end{array}$ & $\begin{array}{l}\text { Both prenatal exposures and } \\
\text { those occurred in the first } \\
\text { two years of life are } \\
\text { associated with an increased } \\
\text { risk of ASD expressed by an } \\
\text { Odds Ratio of } 1.51 \text {, } \\
95 \% \text { CI = } 1.10-2.26 \text { ) }\end{array}$ \\
\hline $\begin{array}{l}\text { Becerra et al., } \\
2013 \text { [30] }\end{array}$ & Case-control & $\begin{array}{l}7603 \text { ASD cases and } 10 \\
\text { controls per case from } \\
\text { Los Angeles, California }\end{array}$ & $\begin{array}{l}\text { The diagnosis of ASD } \\
\text { was based on the } \\
\text { Diagnostic and } \\
\text { Statistical Manual of } \\
\text { Mental Disorders, } 4 \text { th } \\
\text { Edition, Text Revision } \\
\text { (DSM-IV-R) }\end{array}$ & $\begin{array}{l}\text { Modeled } \\
\text { concentrations of } \mathrm{PM}_{2.5} \\
\text { from air monitoring } \\
\text { station } 1993-2006, \\
\text { assigned by residential } \\
\text { address at } \\
\text { delivery/birth }\end{array}$ & $\begin{array}{l}\text { Conditional logistic } \\
\text { regression }\end{array}$ & $\begin{array}{l}\text {-maternal age } \\
\text {-maternal place of birth } \\
\text {-race } \\
\text {-education } \\
\text {-type of birth } \\
\text {-parity } \\
\text {-insurance type } \\
\text {-gestational age at birth }\end{array}$ & -pregnancy & $\begin{array}{l}\text { Association with } \mathrm{PM}_{2.5} \\
\text { during pregnancy and ASD } \\
\text { with an OR of } 1.15(1.06, \\
1.24) \text { per interquartile range } \\
\text { (IIR) increase per } \\
4.68 \mu \mathrm{\mu g} / \mathrm{m}^{3}\end{array}$ \\
\hline
\end{tabular}


Table 1. Cont.

\begin{tabular}{|c|c|c|c|c|c|c|c|c|}
\hline Authors and Year & Study Design & Sample Size/Country & $\begin{array}{l}\text { ASD Outcome } \\
\text { Assessment }\end{array}$ & Exposure Assessment & Method of Analysis & Adjustment Variables & $\begin{array}{c}\text { Time Window of } \\
\text { Exposure }\end{array}$ & Main Findings \\
\hline $\begin{array}{l}\text { Volk et al., } \\
2013 \text { [31] }\end{array}$ & Case-control & $\begin{array}{l}279 \text { ASD cases and } 245 \\
\text { controls from } \\
\text { California }\end{array}$ & $\begin{array}{l}\text { ASD case classification } \\
\text { based on the results } \\
\text { from the ADOS } \\
\text { (Autism Diagnostic } \\
\text { Observation Schedule) } \\
\text { and ADI-R (Autism } \\
\text { Diagnostic } \\
\text { Interview-Revised) }\end{array}$ & $\begin{array}{l}\text { Traffic-related air } \\
\text { pollution was assigned } \\
\text { to each mother's } \\
\text { location using a } \\
\text { line-source air-quality } \\
\text { dispersion model }\end{array}$ & $\begin{array}{l}\text { Logistic additive } \\
\text { models }\end{array}$ & $\begin{array}{l}\text {-child gender } \\
\text {-child ethnicity } \\
\text {-maximal education of } \\
\text { parents } \\
\text {-maternal age } \\
\text {-prenatal smoking }\end{array}$ & $\begin{array}{l}\text {-pregnancy } \\
\text {-trimester 1, 2, 3, } \\
\text {-year 1 }\end{array}$ & $\begin{array}{l}\text { Exposure to } \mathrm{PM}_{2.5} \text {, during } \\
\text { pregnancy and during the } \\
\text { first year of life was } \\
\text { associated with ASD with } \\
\text { an OR of } 2.08(95 \% \mathrm{CI} \\
1.93-2.25) \text { Exposure to } \mathrm{PM}_{10} \\
\text { in the prenatal period was } \\
\text { associated with ASD with } \\
\text { an OR of } 2.17(1.49,3.16) \text { per } \\
\text { each increase of } 14.6 \mu \mathrm{gg} / \mathrm{m}^{3} \\
\text { in IQR value }\end{array}$ \\
\hline Jo et al., 2019 [32] & Cohort & $\begin{array}{l}246,420 \text { children from } \\
\text { Southern California }\end{array}$ & $\begin{array}{l}\text { ASD diagnosis } \\
\text { according to } \\
\text { International } \\
\text { Classification of } \\
\text { Diseases, Ninth } \\
\text { Revision, Clinical } \\
\text { Modification } \\
\text { (ICD-9-CM) }\end{array}$ & $\begin{array}{l}\mathrm{PM}_{2.5} \text { measured at } \\
\text { regulatory air } \\
\text { monitoring stations } \\
\text { was interpolated to } \\
\text { estimate exposures } \\
\text { during preconception } \\
\text { and each pregnancy } \\
\text { trimester, and first year } \\
\text { of life at each child's } \\
\text { birth address }\end{array}$ & Cox regression models & $\begin{array}{l}\text {-birth year } \\
\text {-relevant maternal and } \\
\text { child characteristics }\end{array}$ & $\begin{array}{l}\text {-preconception } \\
\text {-trimester 1,2,3 } \\
\text {-year } 1\end{array}$ & $\begin{array}{l}\text { Statistically significant } \\
\text { association between } \\
\text { exposures to PM } 2.5 \text { and risk } \\
\text { of ASD quantified by the } \\
\text { following Hazard Ratios } \\
\text { (HR) per each increase of } \\
6.5 \mu \mathrm{\mu g} / \mathrm{m}^{3} \text { in IQR values in } \\
\text { different phases of the } \\
\text { pregnancy: } 1.17 \text { ( } 95 \% \mathrm{CI} \\
1.04-1.33 \text { ) in the entire } \\
9-\text { months period; } 1.10 \\
(95 \% \mathrm{CI}, 1.02-1.19) \text { in the } \\
\text { first trimester of pregnancy, } \\
1.08(95 \% \mathrm{CI}, 1.00-1.18) \text { in } \\
\text { the third trimester of } \\
\text { pregnancy; } 1.21 \text { ( } 95 \% \mathrm{CI} \text {, } \\
1.05-1.40) \text { in the first year } \\
\text { of life }\end{array}$ \\
\hline $\begin{array}{l}\text { Pagalan et al., } \\
\quad 2019 \text { [33] }\end{array}$ & Cohort & $\begin{array}{l}\text { Cohort of } 129,439 \\
\text { children: } 1276 \text { were } \\
\text { diagnosed with ASD } \\
\text { from Metro Vancouver, } \\
\text { British Columbia, } \\
\text { Canada }\end{array}$ & $\begin{array}{l}\text { ASD case classification } \\
\text { based on the results } \\
\text { from the ADOS } \\
\text { (Autism Diagnostic } \\
\text { Observation Schedule) } \\
\text { and ADI-R (Autism } \\
\text { Diagnostic } \\
\text { Interview-Revised) }\end{array}$ & $\begin{array}{l}\text { Monthly mean } \\
\text { exposures to PM }{ }_{2.5} \text {, at } \\
\text { the maternal residence } \\
\text { during pregnancy were } \\
\text { estimated with } \\
\text { temporally adjusted, } \\
\text { high-resolution land } \\
\text { use regression models }\end{array}$ & $\begin{array}{l}\text { Logistic regression } \\
\text { model }\end{array}$ & $\begin{array}{l}\text {-child sex } \\
\text {-birth month } \\
\text {-birth year } \\
\text {-maternal age } \\
\text {-maternal birthplace } \\
\text {-neighborhood level } \\
\text { urbanicity and income } \\
\text { band }\end{array}$ & -pregnancy & $\begin{array}{l}\text { No significant association } \\
\text { between } \mathrm{PM}_{2.5} \text { and ASD }\end{array}$ \\
\hline
\end{tabular}


Table 1. Cont.

\begin{tabular}{|c|c|c|c|c|c|c|c|c|}
\hline Authors and Year & Study Design & Sample Size/Country & $\begin{array}{l}\text { ASD Outcome } \\
\text { Assessment }\end{array}$ & Exposure Assessment & Method of Analysis & Adjustment Variables & $\begin{array}{l}\text { Time Window of } \\
\text { Exposure }\end{array}$ & Main Findings \\
\hline $\begin{array}{l}\text { Guxens et al., } \\
2016 \text { [34] }\end{array}$ & Cohort & $\begin{array}{l}8079 \text { children from four } \\
\text { European } \\
\text { population-based } \\
\text { birth/child cohorts } \\
\text { (Sweden, Netherlands, } \\
\text { Italy, and Spain) }\end{array}$ & $\begin{array}{l}\text { Autistic traits were } \\
\text { assessed in children } \\
\text { using:-the Autism } \\
\text { Spectrum Disorder } \\
\text { module of the } \\
\text { Autism-Tics, } \\
\text { Attention Deficit and } \\
\text { Hyperactivity } \\
\text { Disorders, and Other } \\
\text { Comorbidities (A-TAC) } \\
\text { inventory in the } \\
\text { Swedish cohort-the } \\
\text { Pervasive } \\
\text { Developmental } \\
\text { Problems (PDP) } \\
\text { subscale of the Child } \\
\text { Behavior Checklist for } \\
\text { Toddlers in the Dutch } \\
\text { cohort and in the Italian } \\
\text { cohort-an adapted } \\
\text { 18-item version of the } \\
\text { Social Responsiveness } \\
\text { Scale (SRS) in the } \\
\text { Dutch cohort at age } \\
\text { 6 years;-the Childhood } \\
\text { Autism Spectrum Test } \\
\text { (CAST) in the } \\
\text { Spanish cohorts }\end{array}$ & $\begin{array}{l}\mathrm{PM}_{2.5} \text { and } \mathrm{PM}_{10} \\
\text { absorbance were } \\
\text { estimated for birth } \\
\text { addresses by land-use } \\
\text { regression models } \\
\text { based on monitoring } \\
\text { campaigns performed } \\
\text { between } 2008 \text { and } 2011 . \\
\text { Levels of exposures } \\
\text { were extrapolated back } \\
\text { in time to exact } \\
\text { pregnancy periods }\end{array}$ & $\begin{array}{l}\text { Logistic regression } \\
\text { model }\end{array}$ & $\begin{array}{l}\text {-age at delivery } \\
\text {-educational level } \\
\text {-country of birth } \\
\text {-prenatal smoking } \\
\text {-parity } \\
\text {-maternal height } \\
\text {-pre-pregnancy weight } \\
\text {-pre-pregnancy body } \\
\text { mass index } \\
\text {-child's sex } \\
\text {-date of birth } \\
\text {-child's age at autistic } \\
\text { trait assessment } \\
\text {-information on the } \\
\text { evaluator of the autistic } \\
\text { traits } \\
\text {-urbanity at child's } \\
\text { birth address }\end{array}$ & -pregnancy & $\begin{array}{l}\text { No significant association } \\
\text { between } \mathrm{PM}_{2.5}, \mathrm{PM}_{10} \\
\text { and ASD }\end{array}$ \\
\hline $\begin{array}{l}\text { Kalkbrenner et al., } \\
2015 \text { [35] }\end{array}$ & Case-Control & $\begin{array}{l}979 \text { ASD cases and } \\
14,666 \text { controls from } \\
\text { North Carolina and San } \\
\text { Francisco Bay Area } \\
\text { in California }\end{array}$ & $\begin{array}{l}\text { The diagnosis of ASD } \\
\text { was based on the } \\
\text { Diagnostic and } \\
\text { Statistical Manual of } \\
\text { Mental Disorders, 4th } \\
\text { Edition, Text Revision } \\
\text { (DSM-IV-R) }\end{array}$ & $\begin{array}{l}\text { Exposure to } \mathrm{PM}_{10} \text { at the } \\
\text { birth address was } \\
\text { assigned to each child } \\
\text { by a geostatistical } \\
\text { interpolation method } \\
\text { using daily } \\
\text { concentrations from air } \\
\text { pollution regulatory } \\
\text { monitors }\end{array}$ & $\begin{array}{l}\text { Logistic generalized } \\
\text { additive models }\end{array}$ & $\begin{array}{l}\text {-year } \\
\text {-state } \\
\text {-race } \\
\text {-maternal education } \\
\text {-maternal age } \\
\text {-the calendar week of } \\
\text { the child's birth }\end{array}$ & $\begin{array}{l}\text {-pre-conception } \\
\text {-trimester 1,2,3 } \\
\text {-postnatal }\end{array}$ & $\begin{array}{l}\text { The results obtained } \\
\text { showed an association with } \\
\text { the third trimester of } \\
\text { pregnancy, with an OR of } \\
1.36(1.13,1.63) \text { per } \\
10 \mu \mathrm{g} / \mathrm{m}^{3} \text { increase in } \\
\text { IQR value }\end{array}$ \\
\hline $\begin{array}{l}\text { Yousefian et al., } \\
2018 \text { [36] }\end{array}$ & Case-Control & $\begin{array}{l}134 \text { ASD cases and } 388 \\
\text { controls from } \\
\text { Tehran, Iran }\end{array}$ & $\begin{array}{l}\text { The diagnosis of ASD } \\
\text { was based on the } \\
\text { Diagnostic and } \\
\text { Statistical Manual of } \\
\text { Mental Disorders, 4th } \\
\text { Edition, Text Revision } \\
\text { (DSM-IV-R) }\end{array}$ & $\begin{array}{l}\text { Land-use regression } \\
\text { models were used to } \\
\text { estimate their annual } \\
\text { mean exposure to } \\
\text { ambient } \mathrm{PM}_{10}\end{array}$ & Logistic regression & $\begin{array}{l}\text {-maternal age at birth } \\
\text {-maternal education } \\
\text {-paternal education } \\
\text {-cousin marriage } \\
\text {-maternal smoking } \\
\text { during pregnancy } \\
\text {-birth order } \\
\text {-gestational age (weeks) } \\
\text {-multiple births } \\
\text {-maternal disease } \\
\text {-paternal disease }\end{array}$ & -pregnancy & $\begin{array}{l}\text { No significant association } \\
\text { between } \mathrm{PM}_{10} \text { and ASD }\end{array}$ \\
\hline
\end{tabular}


Table 1. Cont

\begin{tabular}{|c|c|c|c|c|c|c|c|c|}
\hline Authors and Year & Study Design & Sample Size/Country & $\begin{array}{l}\text { ASD Outcome } \\
\text { Assessment }\end{array}$ & Exposure Assessment & Method of Analysis & Adjustment Variables & $\begin{array}{c}\text { Time Window of } \\
\text { Exposure }\end{array}$ & Main Findings \\
\hline $\begin{array}{l}\text { Gong et al., } \\
2017 \text { [37] }\end{array}$ & Case-Control & $\begin{array}{l}5136 \text { ASD cases } 18,237 \\
\text { controls from Sweden }\end{array}$ & $\begin{array}{l}\text { The diagnosis of ASD } \\
\text { was based on the } \\
\text { Diagnostic and } \\
\text { Statistical Manual of } \\
\text { Mental Disorders, 4th } \\
\text { Edition, Text Revision } \\
\text { (DSM-IV-R) }\end{array}$ & $\begin{array}{l}\text { Levels of PM } 10 \text { from } \\
\text { road traffic were } \\
\text { estimated at residential } \\
\text { addresses during } \\
\text { mother's pregnancy } \\
\text { and the child's first } \\
\text { year of life by } \\
\text { dispersion models }\end{array}$ & $\begin{array}{l}\text { Logistic regression } \\
\text { model }\end{array}$ & $\begin{array}{l}\text {-municipality } \\
\text {-calendar year of birth }\end{array}$ & $\begin{array}{l}\text {-pregnancy } \\
\text {-first year of life }\end{array}$ & $\begin{array}{l}\text { No significant association } \\
\text { between } \mathrm{PM}_{10} \text { and ASD }\end{array}$ \\
\hline $\begin{array}{l}\text { Jung et al., } \\
2013 \text { [39] }\end{array}$ & Case-Control & $\begin{array}{l}49,073 \text { children } \\
\text { from Taiwan }\end{array}$ & $\begin{array}{l}\text { ASD diagnosis } \\
\text { according to } \\
\text { International } \\
\text { Classification of } \\
\text { Diseases, Ninth } \\
\text { Revision, Clinical } \\
\text { Modification } \\
\text { (ICD-9-CM) }\end{array}$ & $\begin{array}{l}\text { Inverse distance } \\
\text { weighting method was } \\
\text { used to form exposure } \\
\text { parameter for } \mathrm{PM}_{10}\end{array}$ & $\begin{array}{l}\text { Cox proportional } \\
\text { hazards }(\mathrm{PH}) \text { model }\end{array}$ & $\begin{array}{l}\text {-age } \\
\text {-anxiety } \\
\text {-gender } \\
\text {-intellectual disabilities } \\
\text {-preterm } \\
\text {-SES }\end{array}$ & -postnatal & $\begin{array}{l}\text { No significant association } \\
\text { between } \mathrm{PM}_{10} \text { and ASD } \\
\text { during the first for years } \\
\text { of life }\end{array}$ \\
\hline $\begin{array}{l}\text { Gong et al., } \\
2014 \text { [38] }\end{array}$ & Longitudinal cohort & $\begin{array}{l}3426 \text { twins born in } \\
\text { Stockholm during } \\
1992-2000\end{array}$ & $\begin{array}{l}\text { The diagnosis of ASD } \\
\text { was based on the } \\
\text { Diagnostic and } \\
\text { Statistical Manual of } \\
\text { Mental Disorders, 4th } \\
\text { Edition, Text Revision } \\
\text { (DSM-IV-R) }\end{array}$ & $\begin{array}{l}\text { Residence } \\
\text { time-weighted } \\
\text { concentrations of } \mathrm{PM}_{10} \\
\text { from road traffic were } \\
\text { estimated at } \\
\text { participants' addresses } \\
\text { using dispersion } \\
\text { modeling, controlling } \\
\text { for seasonal variation }\end{array}$ & $\begin{array}{l}\text { Multivariate } \\
\text { regression models }\end{array}$ & $\begin{array}{l}\text {-parity } \\
\text {-gender } \\
\text {-maternal age during } \\
\text { pregnancy } \\
\text {-maternal smoking } \\
\text { during pregnancy } \\
\text {-maternal marital status } \\
\text { at birth year } \\
\text {-parental education } \\
\text {-family income } \\
\text {-neighborhood } \\
\text { deprivation at } \\
\text { birth year }\end{array}$ & $\begin{array}{l}\text {-pregnancy } \\
\text {-year } 1 \\
\text {-year } 9\end{array}$ & $\begin{array}{l}\text { No significant association } \\
\text { between } \mathrm{PM}_{10} \text { and ASD }\end{array}$ \\
\hline
\end{tabular}




\subsection{Association between $\mathrm{NO}_{2}$ and $A S D$}

Several studies evaluated the association between maternal exposure to $\mathrm{NO}_{2}$ during pregnancy and in the first few years of the child's life and the risk of the onset of ASD. In 2018, a study conducted on the Israeli population which enrolled 2098 cases and 54,191 controls, assessed maternal exposure during pregnancy and in the first nine months of the child's life using dispersion models. The OR obtained through logistic regression was of 1.40 (95\%CI: 1.09, 1.80) per IQR increase for $5.85 \mathrm{ppb}$ showing that postnatal exposure to $\mathrm{NO}_{2}$ is associated with an increased risk of ASD diagnosis [40].

Again, the study of Ritz et al., already described above, evaluated also the possible relation between $\mathrm{NO}_{2}$ exposure and the increased risk of ASD. The data obtained showed that exposure to $\mathrm{NO}_{2}$ during the entire period of pregnancy increases the risk of a diagnosis of ASD. In particular, the authors estimated an adjusted OR of 1.08 (95\%CI: 1.01, 1.15) for ASD per IQR increase for $11.41 \mu \mathrm{g} / \mathrm{m}^{3}$ in $\mathrm{NO}_{2}$ [26].

A 2018 study assessed the joint effects of taking folic acid in pregnancy and exposure to $\mathrm{NO}_{2}$ in association with the risk of diagnosing ASD. The survey recruited the CHARGE study participants ( 346 cases and 260 controls). This study showed that taking folic acid during pregnancy reduces the risk of ASD among those exposed to high $\mathrm{NO}_{2}$ levels in the prenatal period [41].

In the aforementioned study by Volk et al., which examined the relationship between traffic-related air pollution and ASD, the exposure to $\mathrm{NO}_{2}$ was also investigated. The results confirmed an association in the prenatal period and the risk of ASD with an OR of $1.81(95 \% \mathrm{CI}, 1.37,3.09)$ [31].

In the same year, a Californian case-control study, previously described, assessed the influence of exposure to environmental pollutants deriving from vehicular traffic during pregnancy on the onset of the ASD. The results obtained highlighted an association between the development of ASD and prenatal exposure to $\mathrm{NO}_{2}$ [30].

However, a Swedish case-control study did not find clear associations between $\mathrm{NO}_{2}$ exposures during pregnancy, the first year of life, and the first nine years of life and ASD [38].

Several cohort studies were also conducted to evaluate the association between maternal exposure to $\mathrm{NO}_{2}$ during pregnancy and in the very early years of the baby's life and the risk of ASD onset.

In 2019 a cohort study was conducted on a Swedish population consisting of 48,571 children born between 1999 and 2009. Exposure to nitrogen oxides (NOx), of which $\mathrm{NO}_{2}$ is the largest component, was assessed using Gaussians dispersion models during the gestational period considering maternal residence. Researchers found associations between NOx exposure during the prenatal period and an increased risk of diagnosis for ASD [42].

Another cohort study conducted in 2013 in Taiwan involved 49,073 children aged up to three years old. Inverse distance weighting method was used to describe exposure parameter for several pollutants, including $\mathrm{NO}_{2}$. A time-dependent Cox proportional hazards model was used to assess the associations between the average exposure to air pollutants of previous years and newly diagnosed ASD children. The study provided evidence of association between $\mathrm{NO}_{2}$ in the first four years of life and an increased risk of ASD [39].

In contrast to the evidence gathered from these studies, two further cohort studies found no statistically significant associations. Actually, a 2019 Canadian cohort study involving 132,256 children born between 2004 and 2009 (with 1307 who had received an ASD diagnosis) found no significant association between $\mathrm{NO}_{2}$ and ASD [33]. Moreover, the study carried out by Guxens et al. (already described above) involving four European countries, assessed also the maternal exposure to $\mathrm{NO}_{2}$ during different periods of pregnancy and its putative relationship with ASD onset without finding out significant evidence [34]. Results for associations between $\mathrm{NO}_{2}$ and ASD are summarized in Table 2. 
Table 2. Studies investigating the association between exposure to $\mathrm{NO}_{2}$ and ASD development.

\begin{tabular}{|c|c|c|c|c|c|c|c|c|}
\hline Authors and Year & Study Design & Sample Size/Country & ASD Outcome Assessment & Exposure Assessment & Method of Analysis & Adjustment Variables & $\begin{array}{c}\text { Time Window of } \\
\text { Exposure }\end{array}$ & Main Findings \\
\hline Ritz et al., 2018 [26] & Case-control & $\begin{array}{l}15,387 \text { ASD cases and } \\
68,139 \text { controls from } \\
\text { Denmark }\end{array}$ & $\begin{array}{l}\text { ASD diagnosis according to } \\
\text { International Classification } \\
\text { of Diseases, Tenth Revision, } \\
\text { Clinical Modification } \\
\text { (ICD-10-CM) }\end{array}$ & $\begin{array}{l}\text { Exposures estimates } \\
\text { provided by the } \\
\text { dispersion models } \\
\text { (AirGIS) for the } \\
\text { detected pollutants } \\
\left(\mathrm{NO}_{2}, \mathrm{SO}_{2}, \mathrm{PM}_{2.5} \text { and }\right. \\
\left.\mathrm{PM}_{10}\right) \text { in relation to the } \\
\text { maternal residence } \\
\text { during the examined } \\
\text { periods }\end{array}$ & $\begin{array}{l}\text { Conditional logistic } \\
\text { regression }\end{array}$ & $\begin{array}{l}\text {-parental age } \\
\text {-neighborhood } \\
\text {-socio-economic } \\
\text { indicators } \\
\text {-maternal smoking }\end{array}$ & $\begin{array}{l}\text {-pregnancy } \\
-9 \text { months after } \\
\text { pregnancy }\end{array}$ & $\begin{array}{l}\text { The data obtained } \\
\text { showed that exposure } \\
\text { during the entire } \\
\text { period of pregnancy to } \\
\mathrm{NO}_{2} \text { increases the risk } \\
\text { of a diagnosis of ASD. } \\
\text { In particular, the } \\
\text { authors estimated an } \\
\text { adjusted ORs for ASD } \\
\text { per IQR increase for } \\
11.41 \mu \mathrm{mg} / \mathrm{m}^{3} \text { with } \mathrm{NO}_{2} \\
\text { of } 1.08(95 \% \mathrm{CI}: 1.01 \text {, } \\
1.15)\end{array}$ \\
\hline Becerra et al., 2013 [30] & Case-control & $\begin{array}{l}7603 \text { ASD cases and } 10 \\
\text { controls per case from } \\
\text { Los Angeles, California }\end{array}$ & $\begin{array}{l}\text { The diagnosis of ASD was } \\
\text { based on the Diagnostic and } \\
\text { Statistical Manual of Mental } \\
\text { Disorders, 4th Edition, Text } \\
\text { Revision (DSM-IV-R) }\end{array}$ & $\begin{array}{l}\text { Modeled } \\
\text { concentrations of } \mathrm{PM}_{2.5} \\
\text { from air monitoring } \\
\text { station 1993-2006, } \\
\text { assigned by residential } \\
\text { address at } \\
\text { delivery/birth }\end{array}$ & $\begin{array}{l}\text { Conditional logistic } \\
\text { regression }\end{array}$ & $\begin{array}{l}\text {-maternal age } \\
\text {-maternal place of birth } \\
\text {-race } \\
\text {-education } \\
\text {-type of birth } \\
\text {-parity } \\
\text {-insurance type } \\
\text {-gestational age at birth }\end{array}$ & -pregnancy & $\begin{array}{l}\text { The results obtained } \\
\text { highlighted an } \\
\text { association between the } \\
\text { development of ASD } \\
\text { and prenatal exposure } \\
\text { to } \mathrm{NO}_{2}\end{array}$ \\
\hline Volk et al., 2013 [31] & Case-control & $\begin{array}{l}279 \text { ASD cases and } 245 \\
\text { controls from } \\
\text { California }\end{array}$ & $\begin{array}{l}\text { ASD case classification } \\
\text { based on the results from } \\
\text { the ADOS (Autism } \\
\text { Diagnostic Observation } \\
\text { Schedule) and ADI-R } \\
\text { (Autism Diagnostic } \\
\text { Interview-Revised) }\end{array}$ & $\begin{array}{l}\text { Traffic-related air } \\
\text { pollution was assigned } \\
\text { to each mother's } \\
\text { location using a } \\
\text { line-source air-quality } \\
\text { dispersion model }\end{array}$ & $\begin{array}{l}\text { Logistic additive } \\
\text { models }\end{array}$ & $\begin{array}{l}\text {-child gender } \\
\text {-child ethnicity } \\
\text {-maximal education of } \\
\text { parents } \\
\text {-maternal age } \\
\text {-prenatal smoking }\end{array}$ & $\begin{array}{l}\text {-pregnancy } \\
\text {-trimester 1, 2, 3, } \\
\text {-year 1 }\end{array}$ & $\begin{array}{l}\text { The results confirmed } \\
\text { an association in the } \\
\text { prenatal period and the } \\
\text { risk of ASD with an OR } \\
\text { of } 1.81\end{array}$ \\
\hline Pagalan et al., 2019 [33] & Cohort & $\begin{array}{l}\text { Cohort of } 129,439 \\
\text { children: } 1276 \text { were } \\
\text { diagnosed with ASD } \\
\text { from Metro Vancouver, } \\
\text { British Columbia, } \\
\text { Canada }\end{array}$ & $\begin{array}{l}\text { ASD case classification } \\
\text { based on the results from } \\
\text { the ADOS (Autism } \\
\text { Diagnostic Observation } \\
\text { Schedule) and ADI-R } \\
\text { (Autism Diagnostic } \\
\text { Interview-Revised) }\end{array}$ & $\begin{array}{l}\text { Monthly mean } \\
\text { exposures to } \mathrm{PM}_{2.5} \text {, at } \\
\text { the maternal residence } \\
\text { during pregnancy were } \\
\text { estimated with } \\
\text { temporally adjusted, } \\
\text { high-resolution land } \\
\text { use regression models }\end{array}$ & $\begin{array}{l}\text { Logistic regression } \\
\text { model }\end{array}$ & $\begin{array}{l}\text {-child sex } \\
\text {-birth month } \\
\text {-birth year } \\
\text {-maternal age } \\
\text {-maternal birthplace } \\
\text {-neighborhood level } \\
\text { urbanicity and income } \\
\text { band. }\end{array}$ & -pregnancy & $\begin{array}{l}\text { No significant } \\
\text { association between } \\
\mathrm{NO}_{2} \text { and ASD }\end{array}$ \\
\hline
\end{tabular}


Table 2. Cont.

\begin{tabular}{|c|c|c|c|c|c|c|c|c|}
\hline Authors and Year & Study Design & Sample Size/Country & ASD Outcome Assessment & Exposure Assessment & Method of Analysis & Adjustment Variables & $\begin{array}{l}\text { Time Window of } \\
\text { Exposure }\end{array}$ & Main Findings \\
\hline Guxens et al., 2016 [34] & Cohort & $\begin{array}{l}8079 \text { children from four } \\
\text { European } \\
\text { population-based } \\
\text { birth/child cohorts } \\
\text { (Sweden, Netherlands, } \\
\text { Italy, and Spain) }\end{array}$ & $\begin{array}{l}\text { Autistic traits were assessed } \\
\text { in children using: } \\
\text {-the Autism Spectrum } \\
\text { Disorder module of the } \\
\text { Autism-Tics, Attention } \\
\text { Deficit and Hyperactivity } \\
\text { Disorders, and Other } \\
\text { Comorbidities (A-TAC) } \\
\text { inventory in the Swedish } \\
\text { cohort } \\
\text {-the Pervasive } \\
\text { Developmental Problems } \\
\text { (PDP) subscale of the Child } \\
\text { Behavior Checklist for } \\
\text { Toddlers in the Dutch cohort } \\
\text { and in the Italian cohort } \\
\text {-an adapted 18-item version } \\
\text { of the Social Responsiveness } \\
\text { Scale (SRS) in the Dutch } \\
\text { cohort at age 6 years; } \\
\text {-the Childhood Autism } \\
\text { Spectrum Test (CAST) in the } \\
\text { Spanish cohorts }\end{array}$ & $\begin{array}{l}\mathrm{PM}_{2.5} \text { absorbance was } \\
\text { estimated for birth } \\
\text { addresses by land-use } \\
\text { regression models } \\
\text { based on monitoring } \\
\text { campaigns performed } \\
\text { between } 2008 \text { and } 2011 . \\
\text { Levels of exposures } \\
\text { were extrapolated back } \\
\text { in time to exact } \\
\text { pregnancy periods }\end{array}$ & $\begin{array}{l}\text { Logistic regression } \\
\text { model }\end{array}$ & $\begin{array}{l}\text {-age at delivery } \\
\text {-educational level } \\
\text {-country of birth } \\
\text {-prenatal smoking } \\
\text {-parity } \\
\text {-maternal height } \\
\text {-pre-pregnancy weight } \\
\text {-pre-pregnancy body } \\
\text { mass index } \\
\text {-child's sex } \\
\text {-date of birth } \\
\text {-child's age at autistic } \\
\text { trait assessment } \\
\text {-information on the } \\
\text { evaluator of the autistic } \\
\text { traits } \\
\text {-urbanity at child's } \\
\text { birth address }\end{array}$ & -pregnancy & $\begin{array}{l}\text { No significant } \\
\text { association between } \\
\mathrm{NO}_{2} \text { and ASD }\end{array}$ \\
\hline Gong et al., 2014 [38] & $\begin{array}{l}\text { Longitudinal } \\
\text { cohort }\end{array}$ & $\begin{array}{l}3426 \text { twins born in } \\
\text { Stockholm during } \\
1992-2000\end{array}$ & $\begin{array}{l}\text { The diagnosis of ASD was } \\
\text { based on the Diagnostic and } \\
\text { Statistical Manual of Mental } \\
\text { Disorders, 4th Edition, Text } \\
\text { Revision (DSM-IV-R) }\end{array}$ & $\begin{array}{l}\text { Residence } \\
\text { time-weighted } \\
\text { concentrations of } \mathrm{PM}_{10} \\
\text { from road traffic were } \\
\text { estimated at } \\
\text { participants' addresses } \\
\text { using dispersion } \\
\text { modeling, controlling } \\
\text { for seasonal variation }\end{array}$ & $\begin{array}{l}\text { Multivariate regression } \\
\text { models }\end{array}$ & $\begin{array}{l}\text {-parity } \\
\text {-gender } \\
\text {-maternal age during } \\
\text { pregnancy } \\
\text {-maternal smoking } \\
\text { during pregnancy } \\
\text {-maternal marital status } \\
\text { at birth year } \\
\text {-parental education } \\
\text {-family income } \\
\text {-neighborhood } \\
\text { deprivation at birth } \\
\text { year }\end{array}$ & $\begin{array}{l}\text {-pregnancy } \\
\text {-year } 1 \\
\text {-year } 9\end{array}$ & $\begin{array}{l}\text { No significant } \\
\text { association between } \\
\mathrm{NO}_{2} \text { and ASD }\end{array}$ \\
\hline
\end{tabular}


Table 2. Cont.

\begin{tabular}{|c|c|c|c|c|c|c|c|c|}
\hline Authors and Year & Study Design & Sample Size/Country & ASD Outcome Assessment & Exposure Assessment & Method of Analysis & Adjustment Variables & $\begin{array}{c}\text { Time Window of } \\
\text { Exposure }\end{array}$ & Main Findings \\
\hline $\begin{array}{l}\text { Goodrich et al., } \\
2018[41]\end{array}$ & Case-Control & $\begin{array}{l}346 \text { ASD cases and } 260 \\
\text { controls from } \\
\text { California }\end{array}$ & $\begin{array}{l}\text { ASD case classification } \\
\text { based on the results from } \\
\text { the ADOS (Autism } \\
\text { Diagnostic Observation } \\
\text { Schedule) and ADI-R } \\
\text { (Autism Diagnostic } \\
\text { Interview-Revised) }\end{array}$ & $\begin{array}{l}\text { Estimates of exposure } \\
\text { to near roadway air } \\
\text { pollution (NRP) and } \\
\text { criteria air pollutant } \\
\text { measures were } \\
\text { assigned based on } \\
\text { maternal residential } \\
\text { history }\end{array}$ & $\begin{array}{l}\text { Logistic regression } \\
\text { model }\end{array}$ & $\begin{array}{l}\text {-self-reported FA intake } \\
\text { for each month of } \\
\text { pregnancy }\end{array}$ & $\begin{array}{l}\text {-pregnancy } \\
\text {-trimester 1, 2,3 }\end{array}$ & $\begin{array}{l}\text { This study showed that } \\
\text { taking folic acid during } \\
\text { pregnancy reduces the } \\
\text { risk of ASD among } \\
\text { those exposed to } \\
\text { prenatal high } \mathrm{NO}_{2} \\
\text { levels }\end{array}$ \\
\hline Raz et al., 2018 [40] & Case-Control & $\begin{array}{l}\text { 2098 ASD cases and } \\
54,191 \text { controls from } \\
\text { Israel }\end{array}$ & $\begin{array}{l}\text { The diagnosis of ASD was } \\
\text { based on the Diagnostic and } \\
\text { Statistical Manual of Mental } \\
\text { Disorders, 4th Edition, Text } \\
\text { Revision (DSM-IV-R) }\end{array}$ & $\begin{array}{l}\mathrm{NO}_{2} \text { Exposure was } \\
\text { based on an optimized } \\
\text { dispersion model }\end{array}$ & Logistic regression & $\begin{array}{l}\text {-year of birth } \\
\text {-calendar month of } \\
\text { birth } \\
\text {-population group } \\
\text {-paternal age } \\
\text {-socioeconomic status }\end{array}$ & $\begin{array}{l}\text {-pre-conception } \\
\text {-pregnancy } \\
\text {-9 months after birth }\end{array}$ & $\begin{array}{l}\text { Postnatal exposure to } \\
\mathrm{NO}_{2} \text { is associated with } \\
\text { an increased risk of } \\
\text { ASD diagnosis with } \\
\text { values of } 1.40 \text { ( } 95 \% \mathrm{CI} \text { : } \\
1.09,1.80) \text { per IQR } \\
\text { increase for } 5.85 \mathrm{ppb}\end{array}$ \\
\hline Oudin et al., 2019 [42] & $\begin{array}{l}\text { Longitudinal } \\
\text { cohort }\end{array}$ & $\begin{array}{l}48,571 \text { children born } \\
\text { between } 1999 \text { and } 2009 \\
\text { in southern Sweden }\end{array}$ & $\begin{array}{l}\text { ASD diagnosis according to } \\
\text { International Classification } \\
\text { of Diseases, Tenth Revision, } \\
\text { Clinical Modification } \\
\text { (ICD-10-CM) }\end{array}$ & $\begin{array}{l}\text { Modelled nitrogen } \\
\text { oxide }\left(\mathrm{NO}_{\mathrm{x}}\right) \text { levels } \\
\text { derived from a } \\
\text { Gaussian dispersion } \\
\text { model }\end{array}$ & $\begin{array}{l}\text { Logistic regression } \\
\text { model }\end{array}$ & $\begin{array}{l}\text {-maternal residency } \\
\text { during pregnancy } \\
\text {-perinatal factors } \\
\text { collected from a } \\
\text { regional birth registry } \\
\text {-socio-economic factors }\end{array}$ & -pregnancy & $\begin{array}{l}\text { Positive associations } \\
\text { between } \mathrm{NO}_{x} \text { exposure } \\
\text { during pregnancy and } \\
\text { ASD with an adjusted } \\
\text { Odds Ratio (OR) of } 1.40 \\
\text { (95\%CI: } 1.02-1.93 \text { ) }\end{array}$ \\
\hline
\end{tabular}




\subsection{Association between $\mathrm{O}_{3}$ and $A S D$}

The association between $\mathrm{O}_{3}$ exposure and ASD onset was investigated in the aforementioned study of Mc Guinn et al. with a positive correlation being identified. There was a variation by exposure time period for the $\mathrm{O}_{3}-\mathrm{ASD}$ relation, with a stronger association observed during the third trimester of pregnancy and an OR of 1.2 (95\%CI: 1.1, 1.4) per $6.6 \mathrm{ppb}$ increase in $\mathrm{O}_{3}$ [22].

The Californian study by Becerra et al.-which examined the influence of air pollution on ASD onset by using LUR model for exposure estimations-highlighted an association between ASD and prenatal exposure to $\mathrm{O}_{3}$. A $12-15 \%$ relative increase in odds of autism for $\mathrm{O}_{3}$ was estimated, with an OR of $1.12(95 \% \mathrm{CI}: 1.06,1.19)$ per $11.54 \mathrm{ppb}$ increase in $\mathrm{O}_{3}[30]$.

Another study investigated the link between ASD and the $\mathrm{O}_{3}$ concentrations to which mothers were exposed during pregnancy and for the first two years of the child's life. The results showed an association with the exposure to high levels of $\mathrm{O}_{3}$ during the second year of life [25].

A cohort study, performed in Taiwan in 2013, generated positive evidence about the association between $\mathrm{O}_{3}$ exposure during the first four years of life and an increased risk of ASD diagnosis [39]. However, another cohort study carried out in California in 2019 did not found significant association [32].

Studies investigating the association between $\mathrm{O}_{3}$ and ASD are summarized in Table 3.

\subsection{Association between $\mathrm{SO}_{2}$ and $A S D$}

In literature, the association between maternal exposure to $\mathrm{SO}_{2}$ during pregnancy and the earliest years of children's life and the risk of ASD onset has been poorly investigated. The study performed by Ritz et al. examined the exposure-at mothers' houses- to different environmental pollutants, among which $\mathrm{SO}_{2}$, during the gestation and in the following nine months by using the AirGIS dispersion model. The authors estimated an OR of 1.21 (95\%CI: 1.13, 1.29) for ASD onset per each increase of $2.8 \mu \mathrm{g} / \mathrm{m}^{3}$ in $\mathrm{SO}_{2}$ for IQR value, nine months after pregnancy [26].

Similarly, a Taiwanese cohort study showed an association between the exposure to $\mathrm{SO}_{2}$ in the first four years of life and the risk of ASD diagnosis. The researchers highlighted a $17 \%$ of increased risk for ASD per each increase of $1 \mathrm{ppb}$ in $\mathrm{SO}_{2}$ levels $(95 \% \mathrm{CI}$ : 1.09 , 1.27) [39].

At the opposite, the study carried out by Yousefian et al. performed in Teheran in 2018 did not found statistically significant associations between the mean level of exposure to $\mathrm{SO}_{2}$ and the risk of developing ASD during childhood [36].

Results of associations between $\mathrm{SO}_{2}$ and ASD are reported in Table 4 . 
Table 3. Studies investigating the association between exposure to $\mathrm{O}_{3}$ and ASD development.

\begin{tabular}{|c|c|c|c|c|c|c|c|c|}
\hline Authors and Year & Study Design & Sample Size/Country & ASD Outcome Assessment & Exposure Assessment & Method of Analysis & Adjustment Variables & $\begin{array}{c}\text { Time Window of } \\
\text { Exposure }\end{array}$ & Main Findings \\
\hline $\begin{array}{l}\text { McGuinn et al., } \\
2020[23]\end{array}$ & Case-control & $\begin{array}{l}674 \text { ASD cases and } 855 \\
\text { controls from California, } \\
\text { Colorado, Georgia, } \\
\text { Maryland, North } \\
\text { Carolina, and } \\
\text { Pennsylvania }\end{array}$ & $\begin{array}{l}\text { ASD case classification } \\
\text { based on the results from } \\
\text { the ADOS (Autism } \\
\text { Diagnostic Observation } \\
\text { Schedule) and ADI-R } \\
\text { (Autism Diagnostic } \\
\text { Interview-Revised) }\end{array}$ & $\begin{array}{l}\text { Satellite-based model } \\
\text { to assign air pollutant } \\
\text { exposure }\left(\mathrm{PM}_{2.5}, \mathrm{O}_{3}\right) \\
\text { averages during several } \\
\text { critical periods of } \\
\text { neurodevelopment }\end{array}$ & $\begin{array}{l}\text { Logistic regression } \\
\text { model }\end{array}$ & $\begin{array}{l}\text {-study site } \\
\text {-maternal age } \\
\text {-maternal education } \\
\text {-maternal race } \\
\text {-maternal smoking, } \\
\text {-month and year of } \\
\text { birth }\end{array}$ & $\begin{array}{l}-3 \text { months before } \\
\text { pregnancy } \\
\text {-each trimester of } \\
\text { pregnancy } \\
\text {-the entire pregnancy } \\
\text {-first year of life }\end{array}$ & $\begin{array}{l}\text { There was a variation } \\
\text { by exposure time } \\
\text { period for the } \mathrm{O}_{3} \text {-ASD } \\
\text { relation, with a stronger } \\
\text { association observed } \\
\text { during the third } \\
\text { trimester of pregnancy } \\
\text { and an OR of } 1.2 \\
(95 \% \text { CI: } 1.1,1.4) \text { per } 6.6 \\
\text { ppb increase in } \mathrm{O}_{3}\end{array}$ \\
\hline Becerra et al., 2013 [30] & Case-control & $\begin{array}{l}7603 \text { ASD cases and } 10 \\
\text { controls per case from } \\
\text { Los Angeles, California }\end{array}$ & $\begin{array}{l}\text { The diagnosis of ASD was } \\
\text { based on the Diagnostic and } \\
\text { Statistical Manual of Mental } \\
\text { Disorders, 4th Edition, Text } \\
\text { Revision (DSM-IV-R) }\end{array}$ & $\begin{array}{l}\text { Modeled } \\
\text { concentrations of } \mathrm{PM}_{2.5} \\
\text { from air monitoring } \\
\text { station 1993-2006, } \\
\text { assigned by residential } \\
\text { address at } \\
\text { delivery/birth }\end{array}$ & $\begin{array}{l}\text { Conditional logistic } \\
\text { regression }\end{array}$ & $\begin{array}{l}\text {-maternal age } \\
\text {-maternal place of birth } \\
\text {-race } \\
\text {-education } \\
\text {-type of birth } \\
\text {-parity } \\
\text {-insurance type } \\
\text {-gestational age at birth }\end{array}$ & -pregnancy & $\begin{array}{l}\text { Positive association } \\
\text { with } \mathrm{O}_{3} \text { during } \\
\text { pregnancy and } \mathrm{ASD} \text {. } \\
1.12(95 \% \mathrm{CI}, 1.06,1.19) \\
\text { per } 11.54 \text { ppb increase } \\
\text { in } \mathrm{O}_{3}\end{array}$ \\
\hline Jo et al., 2019 [32] & Cohort & $\begin{array}{l}246,420 \text { children from } \\
\text { Southern California }\end{array}$ & $\begin{array}{l}\text { ASD diagnosis according to } \\
\text { International Classification } \\
\text { of Diseases, Ninth Revision, } \\
\text { Clinical Modification } \\
\text { (ICD-9-CM) }\end{array}$ & $\begin{array}{l}\mathrm{PM}_{2.5} \text { measured at } \\
\text { regulatory air } \\
\text { monitoring stations } \\
\text { was interpolated to } \\
\text { estimate exposures } \\
\text { during preconception } \\
\text { and each pregnancy } \\
\text { trimester, and first year } \\
\text { of life at each child's } \\
\text { birth address }\end{array}$ & Cox regression models & $\begin{array}{l}\text {-birth year } \\
\text {-relevant maternal and } \\
\text { child characteristics }\end{array}$ & $\begin{array}{l}\text {-preconception } \\
\text {-trimester 1,2,3 } \\
\text {-year 1 }\end{array}$ & $\begin{array}{l}\text { No significant } \\
\text { association between } \mathrm{O}_{3} \\
\text { and ASD }\end{array}$ \\
\hline Jung et al., 2013 [39] & Case-Control & $\begin{array}{l}49,073 \text { children from } \\
\text { Taiwan }\end{array}$ & $\begin{array}{l}\text { ASD diagnosis according to } \\
\text { International Classification } \\
\text { of Diseases, Ninth Revision, } \\
\text { Clinical Modification } \\
\text { (ICD-9-CM) }\end{array}$ & $\begin{array}{l}\text { Inverse distance } \\
\text { weighting method was } \\
\text { used to form exposure } \\
\text { parameter for } \mathrm{PM}_{10}\end{array}$ & $\begin{array}{l}\text { Cox proportional } \\
\text { hazards }(\mathrm{PH}) \text { model }\end{array}$ & $\begin{array}{l}\text {-age } \\
\text {-anxiety } \\
\text {-gender } \\
\text {-intellectual disabilities } \\
\text {-preterm } \\
\text {-SES }\end{array}$ & -postnatal & $\begin{array}{l}\text { The study suggested an } \\
\text { association between } \mathrm{O}_{3} \\
\text { exposure in the first for } \\
\text { years of life and ASD }\end{array}$ \\
\hline
\end{tabular}


Table 4. Studies investigating the association between exposure to $\mathrm{SO}_{2}$ and $\mathrm{ASD}$ development.

\begin{tabular}{|c|c|c|c|c|c|c|c|c|}
\hline Authors and Year & Study Design & Sample Size/Country & ASD Outcome Assessment & Exposure Assessment & Method of Analysis & Adjustment Variables & $\begin{array}{c}\text { Time Window of } \\
\text { Exposure }\end{array}$ & Main Findings \\
\hline Ritz et al., 2018 [26] & Case-control & $\begin{array}{l}15,387 \text { ASD cases and } \\
68,139 \text { controls from } \\
\text { Denmark }\end{array}$ & $\begin{array}{l}\text { ASD diagnosis according to } \\
\text { International Classification } \\
\text { of Diseases, Tenth Revision, } \\
\text { Clinical Modification } \\
\text { (ICD-10-CM) }\end{array}$ & $\begin{array}{l}\text { Exposures estimates } \\
\text { provided by the } \\
\text { dispersion models } \\
\text { (AirGIS) for the } \\
\text { detected pollutants } \\
\left(\mathrm{NO}_{2}, \mathrm{SO}_{2}, \mathrm{PM}_{2.5} \text { and }\right. \\
\left.\mathrm{PM}_{10}\right) \text { in relation to the } \\
\text { maternal residence } \\
\text { during the examined } \\
\text { periods }\end{array}$ & $\begin{array}{l}\text { Conditional logistic } \\
\text { regression }\end{array}$ & $\begin{array}{l}\text {-parental age } \\
\text {-neighborhood } \\
\text {-socio-economic } \\
\text { indicators } \\
\text {-maternal smoking }\end{array}$ & $\begin{array}{l}\text {-pregnancy } \\
-9 \text { months after } \\
\text { pregnancy }\end{array}$ & $\begin{array}{l}\text { The authors estimated } \\
\text { an OR of } 1.21 \text { ( } 95 \% \mathrm{CI} \text { : } \\
1.13,1.29 \text { ) for ASD } \\
\text { onset per each increase } \\
\text { of } 2.8 \mu \mathrm{g} / \mathrm{m}^{3} \mathrm{SO}_{2} \text { in } \\
\text { IQR value, } 9 \text { months } \\
\text { after pregnancy }\end{array}$ \\
\hline Jung et al., 2013 [39] & Case-Control & $\begin{array}{l}49,073 \text { children from } \\
\text { Taiwan }\end{array}$ & $\begin{array}{l}\text { ASD diagnosis according to } \\
\text { International Classification } \\
\text { of Diseases, Ninth Revision, } \\
\text { Clinical Modification } \\
\text { (ICD-9-CM). }\end{array}$ & $\begin{array}{l}\text { Inverse distance } \\
\text { weighting method was } \\
\text { used to form exposure } \\
\text { parameter for } \mathrm{PM}_{10}\end{array}$ & $\begin{array}{l}\text { Cox proportional } \\
\text { hazards }(\mathrm{PH}) \text { model }\end{array}$ & $\begin{array}{l}\text {-age } \\
\text {-anxiety } \\
\text {-gender } \\
\text {-intellectual disabilities } \\
\text {-preterm } \\
\text {-SES }\end{array}$ & -postnatal & $\begin{array}{l}\text { The researchers } \\
\text { highlighted a 17\% } \\
\text { increased risk for ASD } \\
\text { per each increase of } \\
1 \text { ppb in } \mathrm{SO}_{2} \text { levels } \\
(95 \% \mathrm{CI} 1.09-1.27)\end{array}$ \\
\hline
\end{tabular}




\section{Discussion}

This review examined a total of 20 studies investigating the association between maternal and early life exposure to air pollutants and ASD in children, addressing the specific burden attributable to different air pollutants $\left(\mathrm{PM}_{2.5}, \mathrm{PM}_{10}, \mathrm{NO}_{2}, \mathrm{O}_{3}\right.$, and $\left.\mathrm{SO}_{2}\right)$.

We found out a marked association between maternal exposure to PM during pregnancy or in the first years of the children's life and the risk of subsequent ASD onset. In turn, this association was found to be stronger with $\mathrm{PM}_{2.5}$ (confirmed in nine case-control studies and three cohort studies) while the association between $\mathrm{PM}_{10}$ and ASD was less evident. However, our analysis showed that half of eight case-control studies selected found a positive association between maternal exposure to $\mathrm{PM}_{10}$ during the pregnancy (particularly in the third trimester) or in the early years of life and ASD onset $[26,27,31,35]$. The remaining four case-control studies did not find the same association $[28,36,37,39]$ as well as the two cohort studies selected in the present review [34,38]. Another air pollutant that has been extensively studied and related to ASD is $\mathrm{NO}_{2}$. The six case-control studies that analyzed the association between maternal or early life exposure to $\mathrm{NO}_{2}$ and ASD onset showed a positive association [26,30,31,39-41]. Moreover, only one out of four cohort studies $[33,34,38,42]$ analyzing this kind of relationship reported a positive association between $\mathrm{NO}_{2}$ exposure during pregnancy or early life and ASD [42].

All the four case-control studies considered in this review generated evidence about the association between maternal or early years of life exposure to $\mathrm{O}_{3}$ and ASD $[23,25,30,39]$.

The evidence, however, is limited with regard to $\mathrm{SO}_{2}$, due to the small number of studies conducted. Two out of three studies reported a positive association between maternal or early life exposure to $\mathrm{SO}_{2}$ and the onset of ASD [26,39].

In summary, while there is some evidence indicating that maternal exposure to $\mathrm{PM}_{2.5}$ may increase the risk of ASD, the effect of $\mathrm{PM}_{10}, \mathrm{O}_{3}, \mathrm{NO}_{2}$, and $\mathrm{SO}_{2}$ on ASD seem to be weaker or limited. An increase in the number of studies for a future meta-analysis would improve the statistical power to identify associations between air pollutants and ASD.

It would also be interesting to understand the possible contribution not only of individual pollutants but also the cumulative burden of mixture of pollutants, usually contaminating environment, food chain, and possibly the amniotic liquid or placenta. Therefore, future works should include improved spatiotemporal estimates of exposure to air toxics, considering computational fluid-dynamics models on community dwelling population during daily life.

A very interesting aspect that emerged from the analysis of the studies considered in this review is the critical "time window", which is the period when exposure to environmental pollutants seems to be most incisive. This period corresponds to pregnancy; indeed, autistic symptoms commonly appear in the second and sometimes the first year of life, indicating a strong likelihood of origins in the prenatal and early postnatal periods. Neurogenesis takes place at an astonishing rate, averaging 250,000 new neurons per minute during gestation resulting in 100 billion neurons at birth [43]. Most of the neuronal growth occurs in the third trimester, when 40,000 synapses are formed per minute. Moreover, brain development comprises an array of qualitatively different processes with overlapping timing: neural tube formation, cell proliferation and differentiation, migration, dendritic arborization, synaptogenesis, apoptosis, formation, and connectivity of cortical mini-columns, and myelination. The synaptogenesis is known to have a major role in ASD, as it accelerates in the middle of the second trimester (but continues until adolescence), whereas neural migration is completed by birth [44].

Evidence on the association between air pollution and neurodevelopmental disorders dramatically increased in the last years. Many studies investigated the risk of developing, in addition to ASD, other disorders such as learning disabilities, attention deficit and hyperactivity disorder (ADHD) when children (or their mother) are exposed to high level of airborne pollutants, showing a possible link [45]. The long-term exposure to air pollution begin in the prenatal period and continue during the lifetime, causing the 
possible onset of chronic adverse outcome such as cancer, cardiovascular and respiratory diseases [46]. Recently, also the cognitive decline in the elderly was associated with atmospheric particles and chemicals [47]. In particular, older adults living in polluted areas showed a decrease in cognitive function and may be at greater risk of experiencing progressive neurodegenerative pathologies such as Alzheimer's disease [48].

Not only the brain, but also another fundamental organ for the regulation of fetal development, such as the placenta, may be influenced by environmental factors. Placenta can be considered as an intermediate matrix having the potential to express, in association with prenatal exposure to air pollution, distinct biological signatures which may be useful as early-life markers of disease development later in life [49]. Indeed, several studies showed that during pregnancy the exposure to an increased level of $\mathrm{PM}\left(\mathrm{PM}_{2.5}\right.$ or $\mathrm{PM}_{10}$ ) was associated with changes in placental epigenetic markers (mainly DNA methylation), transcriptomic, and proteomic biomarkers which should be extensively studied to understand the possible consequences on fetus health and adult life [49].

Although the results obtained from the studies analyzed in this review seem to confirm that some airborne environmental pollutants can play an important role in the complex etiology of ASD, they represent only a part of the search for environmental causative agents determining ASD. This kind of investigation must take into account a wider range of exposures concerning contaminants in the air, water, soil, and food. The studies analyzed in our review are moving in this direction, since other variables that influence the biology and, therefore, the health was taken into consideration: nutrition, smoking, financial, educational, and social aspects, the structure of the family, living place (urban/suburban/rural environment), workplaces, and microbiome. Unlike the inherited nuclear DNA, these exposures represent modifiable factors, thus opening the door to preventive interventions at various levels. In an epigenetic perspective of the research on autism, it is crucial to reduce the exposures to environmental risk factors [14].

Another field of investigation may be the comparison of the incidence and prevalence rates of ASD between a highly polluted area, where it is assumed that there may be a greater risk of occurrence of ASD, and a control area, in order to understand how cases are distributed in the two areas. Moreover, it would also be interesting to investigate if children born during the spring of 2020, when lockdown measures, due to the spread of SARS-CoV-2, resulted in decreased $\mathrm{PM}_{2.5}$ levels in highly polluted cities, will lead to a decrease in ASD cases compared to the years 2018-2019.

What emerged from the comparison of the studies we selected in this review was the great heterogeneity of the results, which could in part be due to the different number of children recruited, the various statistical methods used for data analysis, and the different ASD assessment systems among studies. The evidence from the case-control studies appeared to be more solid than that from the cohort studies and this could be explained by analyzing the different methods of assessing exposure to air pollution and confounding factors that represented potential bias in some case-control studies.

Confounding due to lifestyle factors, such as smoking in pregnancy, including active smoking and passive smoking, could be problematic, as this factor might be directly associated with an increased risk of the onset of ASD, as reported in several studies [50,51].

Another potential confounding factor could be that related to socio-economic position at the individual and residential area level. In this context, Miranda et al. found that poorer and minority neighborhoods were more likely to experience higher levels of pollution and were also highly correlated with an increased burden of disease. Despite the important need to adjust to these confounding factors, not all of the studies we reviewed corrected or examined the modification of effects based on the socioeconomic position of individuals or their communities [52].

Since it is necessary to further establish the direct associations between air pollution and adverse neurological effects, such as the onset of ASD, the assessment of exposure to air pollution is a crucial element for future studies. Many studies used a binary exposure measurement, i.e., they compared a high-pollution area versus a low-pollution area by 
measuring the annual concentrations of air pollutants from the surrounding monitoring stations or taking into account distance from traffic routes as an estimate of atmospheric pollution. These exposure measurements can lead to incorrect exposure classification and, for this reason, it is crucial to develop more accurate methods for measuring chronic exposure to air pollution in this field.

To get a more precise estimate of air pollution exposure, the most accurate method would be to evaluate and quantify individual exposures. Personal monitoring could provide an exposure estimate that is less prone to misclassification than other methods of measuring exposure to air pollution, especially when taking into account well-defined time windows such as the first 1000 days of the life of the child, including nine months of gestation and the first two years of the child's life. However, this is more difficult to do if we examine a large cohort of subjects, so this motivation could explain the lower evidence found in the cohort studies.

In this context, a LUR model, can integrate personal monitoring and biomonitoring methods including GIS parameters, such as traffic density, population density, which are used to predict small-scale spatial variation of pollutants [53,54]. However, this approach has limitations regarding the estimation of air pollution levels referred to the address of residence as ignores historical exposures since people are constantly on the move and are not confined to the place where the exposure was assessed bringing to a potential misclassification of exposure.

In order to reduce the potential for misclassification of exposure, efforts should be made to include information on individual residency history and length of stay in LUR templates.

In general, the studies we included in our review had critical points, such as the recruitment of small cohorts, the poor comparisons among different areas characterized by different kinds of pollution, the lack of use of a standardized statistical method, the use of different models for assessing the level of exposure to pollutants, and the difficulty of quantifying the exposure both for single molecules or their mixture. Furthermore, air pollution is a complex mixture of toxins for which the biological effects on the development of ASD of individual agents are hard to identify considering also the synergistic effects that the various pollutants could have. Therefore, further studies must take into consideration samples to be compared to many areas, ensuring that the participants were exposed to a wide range of pollutant concentrations with individual-level exposure measurements to multiple compounds by various pathways (air, water, and diet), combined with genetic information.

In addition, the use of exposure biomarkers-which are able to highlight a biological alteration caused by air pollution-could represent a more effective method for measuring these exposures and can be combined with the direct detection of pollutants. Indeed, the subjects' response to air pollution can be variable and depends on individual susceptibility.

In this way, it would be possible to identify people who actually suffered damages caused by airborne chemicals and this data could be correlated with the risk of ASD. For example, micronuclei could be considered, as they are biomarkers of early biological effect which can detect the presence of initial (and reversible) alterations in the chromosomal structure and oxidative damage to DNA caused by air pollution exposure $[55,56]$.

Moreover, in order to quantify individual exposures to specific environmental pollutants, further studies should examine also epigenetic alterations which determine changes in gene expression without altering DNA sequence [57]. These modifications, which include DNA methylation, histone modifications, and microRNAs (miRNAs) expression, operate together in a synergic manner, influencing genome expression patterns and functions in response to exogenous stimuli or exposure [58-60].

Biomarkers that reflect specific exposures have the potential to measure the real integrated internal dose from all routes of complex environmental exposures. In particular, miRNAs have been studied as biomarkers in various diseases and have shown potential as environmental exposure biomarkers [61,62]. Several studies have suggested that environ- 
mental factors may interact with the genetic factors to increase the risk of ASD [10,63-65]. Although today there are still no clear associations between specific miRNAs and specific pollutants, these epigenetic markers are promising and could represent one of those factors explaining the link between genetics and environment [66].

\section{Conclusions}

Air pollution should be considered among the emerging risk factors for ASD. The relationship identified between airborne pollutants and ASD in the studies analyzed in this review must necessarily be confirmed and implemented by further epidemiological studies with more personalized assessment of indoor and outdoor exposure measurements (i.e., through biomarkers of exposure), including more confounders, and using both single pollutant and multiple pollutant statistical models. Moreover, also toxicological studies are needed to understand which molecular pathways are involved in the development of ASD and whether they may result altered after the exposure to specific pollutants. All these efforts will be necessary to determine whether there are causal associations with air pollution and ASD onset or not.

Author Contributions: Conceptualization, Methodology, Writing-Original Draft, G.I.; Data Curation, Writing-Original Draft, A.P.; Formal analysis, Writing-Review and Editing, T.G.; Resources, Data Curation, A.I.; Resources, F.S.; Supervision, Methodology, G.D.F.; Supervision, Methodology, F.B.; Resources, Visualization, D.D.G.; Supervision, G.A.; Writing-Review and Editing, P.P.; Resources, Data Curation, M.C.; Resources, Data Curation, L.P.; Resources, M.R.T.; Formal analysis, R.D.M.; Supervision, A.M.; Project administration, A.D.D. All authors have read and agreed to the published version of the manuscript.

Funding: This research did not receive any specific grant from funding agencies in the public, commercial, or not-for-profit sectors.

Institutional Review Board Statement: Not applicable.

Informed Consent Statement: Not applicable.

Conflicts of Interest: The authors report no conflict of interest.

\section{References}

1. Lai, M.C.; Lombardo, M.V.; Baron-Cohen, S. Autism. Lancet 2014, 383, 896-910. [CrossRef]

2. Maenner, M.J.; Shaw, K.A.; Baio, J.; Washington, A.; Patrick, M.; Di Rienzo, M.; Christensen, D.L.; Wiggins, L.D.; Pettygrove, S.; Andrews, J.G. Prevalence of autism spectrum disorder among children aged 8 years-Autism and developmental disabilities monitoring network, 11 sites, United States, 2016. MMWR Surveill. Summ. 2020, 69, 1.

3. Baio, J.; Wiggins, L.; Christensen, D.L.; Maenner, M.J.; Daniels, J.; Warren, Z.; Kurzius-Spencer, M.; Zahorodny, W.; Robinson Rosenberg, C.; White, T. Prevalence of autism spectrum disorder among children aged 8 years-Autism and developmental disabilities monitoring network, 11 sites, United States, 2014. MMWR Surveill. Summ. 2018, 67, 1. [CrossRef] [PubMed]

4. Christensen, D.L.; Braun, K.V.N.; Baio, J.; Bilder, D.; Charles, J.; Constantino, J.N.; Daniels, J.; Durkin, M.S.; Fitzgerald, R.T.; Kurzius-Spencer, M. Prevalence and characteristics of autism spectrum disorder among children aged 8 years-Autism and developmental disabilities monitoring network, 11 sites, United States, 2012. MMWR Surveill. Summ. 2018, 65, 1. [CrossRef] [PubMed]

5. Elsabbagh, M.; Divan, G.; Koh, Y.J.; Kim, Y.S.; Kauchali, S.; Marcín, C.; Yasamy, M.T. Global prevalence of autism and other pervasive developmental disorders. Autism Res. 2012, 5, 160-179. [CrossRef] [PubMed]

6. American Psychiatric Association. Diagnostic and Statistical Manual of Mental Disorders (DSM-5®); American Psychiatric Pub: Washington, DC, USA, 2013.

7. Rice, C.E.; Rosanoff, M.; Dawson, G.; Durkin, M.S.; Croen, L.A.; Singer, A.; Yeargin-Allsopp, M. Evaluating Changes in the Prevalence of the Autism Spectrum Disorders (ASDs). Public Health Rev. 2012, 34, 17. [CrossRef]

8. Dawson, G.; Bernier, R. A quarter century of progress on the early detection and treatment of autism spectrum disorder. Dev. Psychopathol. 2013, 25 Pt 2, 1455-1472.

9. Belger, A.; Carpenter, K.L.; Yucel, G.H.; Cleary, K.M.; Donkers, F.C. The neural circuitry of autism. Neurotox. Res. 2011, 20, 201-214. [CrossRef]

10. Chaste, P.; Leboyer, M. Autism risk factors: Genes, environment, and gene-environment interactions. Dialogues Clin. Neurosci. 2012, 14, 281-292. 
11. Banerjee, S.; Riordan, M.; Bhat, M.A. Genetic aspects of autism spectrum disorders: Insights from animal models. Front. Cell. Neurosci. 2014, 8, 5 .

12. Bourgeron, T. From the genetic architecture to synaptic plasticity in autism spectrum disorder. Nat. Rev. Neurosci. 2015, 16, 551-563. [CrossRef] [PubMed]

13. Courchesne, E. Brain development in autism: Early overgrowth followed by premature arrest of growth. Ment. Retard. Dev. Disabil. Res. Rev. 2004, 10, 106-111. [CrossRef] [PubMed]

14. Hertz-Picciotto, I.; Schmidt, R.J.; Krakowiak, P. Understanding environmental contributions to autism: Causal concepts and the state of science. Autism Res. 2018, 11, 554-586. [PubMed]

15. Lam, J.; Sutton, P.; Kalkbrenner, A.; Windham, G.; Halladay, A.; Koustas, E.; Lawler, C.; Davidson, L.; Daniels, N.; Newschaffer, C.; et al. A Systematic Review and Meta-Analysis of Multiple Airborne Pollutants and Autism Spectrum Disorder. PLoS ONE 2016, 11, e0161851. [CrossRef] [PubMed]

16. Grova, N.; Schroeder, H.; Olivier, J.-L.; Turner, J.D. Epigenetic and Neurological Impairments Associated with Early Life Exposure to Persistent Organic Pollutants. Int. J. Genom. 2019, 2019, 1-19. [CrossRef] [PubMed]

17. Buoli, M.; Serati, M.; Caldiroli, A.; Cremaschi, L.; Carlo Altamura, A. Neurodevelopmental versus neurodegenerative model of schizophrenia and bipolar disorder: Comparison with physiological brain development and aging. Psychiatr. Danub. 2017, 29, 24-27.

18. Calderón-Garcidueñas, L.; Torres-Jardón, R.; Avila-Ramírez, J.; Kulesza, R.J.; Angiulli, A.D. Air pollution and your brain: What do you need to know right now. Prim. Health Care Res. Dev. 2014, 16, 329-345. [CrossRef]

19. Madrigano, J.; Baccarelli, A.; Mittleman, M.A.; Sparrow, D.; Vokonas, P.S.; Tarantini, L.; Schwartz, J. Aging and epigenetics: Longitudinal changes in gene-specific DNA methylation. Epigenetics 2012, 7, 63-70.

20. Brockmeyer, S.; D'Angiulli, A. How air pollution alters brain development: The role of neuroinflammation. Transl. Neurosci. 2016, 7, 24-30.

21. Moher, D.; Liberati, A.; Tetzlaff, J.; Altman, D.G.; The PRISMA Group. Preferred Reporting Items for Systematic Reviews and Meta-Analyses: The PRISMA Statement. PLoS Med. 2009, 6, e1000097. [CrossRef]

22. CEBM Levels of Evidence. 2009. Available online: www.cebm.net/oxford-centre-evidence-based-medicine-levels-evidencemarch-2009/ (accessed on 15 July 2020).

23. McGuinn, L.A.; Windham, G.C.; Kalkbrenner, A.E.; Bradley, C.; Di, Q.; Croen, L.A.; Fallin, M.D.; Hoffman, K.; Ladd-Acosta, C.; Schwartz, J. Early Life Exposure to Air Pollution and Autism Spectrum Disorder: Findings from a Multisite Case-Control Study. Epidemiology 2020, 31, 103-114. [CrossRef] [PubMed]

24. McGuinn, L.A.; Windham, G.C.; Messer, L.C.; Di, Q.; Schwartz, J.; Croen, L.A.; Lisa, A.f.; Moody, E.J.; Rappold, A.G.; Richardson, D.B. Air pollution, neighborhood deprivation, and autism spectrum disorder in the Study to Explore Early Development. Environ. Epidemiol. 2019, 3, e067. [CrossRef] [PubMed]

25. Kaufman, J.A.; Wright, J.M.; Rice, G.; Connolly, N.; Bowers, K.; Anixt, J. Ambient ozone and fine particulate matter exposures and autism spectrum disorder in metropolitan Cincinnati, Ohio. Environ. Res. 2019, 171, 218-227. [CrossRef]

26. Ritz, B.; Liew, Z.; Yan, Q.; Cui, X.; Virk, J.; Ketzel, M.; Raaschou-Nielsen, O. Air pollution and autism in Denmark. Environ. Epidemiol. 2018, 2, e028. [CrossRef] [PubMed]

27. Chen, G.; Jin, Z.; Li, S.; Jin, X.; Tong, S.; Liu, S.; Yang, Y.; Huang, H.; Guo, Y. Early life exposure to particulate matter air pollution (PM1, PM2.5 and PM10) and autism in Shanghai, China: A case-control study. Environ. Int. 2018, 121, 1121-1127. [CrossRef] [PubMed]

28. Raz, R.; Roberts, A.L.; Lyall, K.; Hart, J.E.; Just, A.C.; Laden, F.; Weisskopf, M.G. Autism Spectrum Disorder and Particulate Matter Air Pollution before, during, and after Pregnancy: A Nested Case-Control Analysis within the Nurses' Health Study II Cohort. Environ. Health Perspect. 2015, 123, 264-270. [CrossRef] [PubMed]

29. Talbott, E.O.; Arena, V.C.; Rager, J.R.; Clougherty, J.E.; Michanowicz, D.R.; Sharma, R.K.; Stacy, S.L. Fine particulate matter and the risk of autism spectrum disorder. Environ. Res. 2015, 140, 414-420. [CrossRef]

30. Becerra, T.A.; Wilhelm, M.; Olsen, J.; Cockburn, M.; Ritz, B. Ambient Air Pollution and Autism in Los Angeles County, California. Environ. Health Perspect. 2013, 121, 380-386.

31. Volk, H.E.; Lurmann, F.; Penfold, B.; Hertz-Picciotto, I.; McConnell, R. Traffic-Related Air Pollution, Particulate Matter, and Autism. JAMA Psychiatry 2013, 70, 71-77. [CrossRef]

32. Jo, H.; Eckel, S.P.; Wang, X.; Chen, J.-C.; Cockburn, M.; Martinez, M.P.; Chow, T.; Molshatzki, N.; Lurmann, F.W.; Funk, W.E.; et al. Sex-specific associations of autism spectrum disorder with residential air pollution exposure in a large Southern California pregnancy cohort. Environ. Pollut. 2019, 254, 113010.

33. Pagalan, L.; Bickford, C.; Weikum, W.; Lanphear, B.; Bauer, M.; Lanphear, N.; Hanley, G.E.; Oberlander, T.F.; Winters, M. Association of Prenatal Exposure to Air Pollution with Autism Spectrum Disorder. JAMA Pediatr. 2019, 173, 86-92. [CrossRef] [PubMed]

34. Guxens, M.; Ghassabian, A.; Gong, T.; Garcia-Esteban, R.; Porta, D.; Giorgis-Allemand, L.; Almqvist, C.; Aranbarri, A.; Beelen, R.; Badaloni, C.; et al. Air Pollution Exposure during Pregnancy and Childhood Autistic Traits in Four European Population-Based Cohort Studies: The ESCAPE Project. Environ. Health Perspect. 2016, 124, 133-140. [CrossRef] [PubMed] 
35. Kalkbrenner, A.E.; Windham, G.C.; Serre, M.L.; Akita, Y.; Wang, X.; Hoffman, K.; Thayer, B.P.; Daniels, J.L. Particulate Matter Exposure, Prenatal and Postnatal Windows of Susceptibility, and Autism Spectrum Disorders. Epidemiology 2015, $26,30-42$. [CrossRef] [PubMed]

36. Yousefian, F.; Mahvi, A.H.; Yunesian, M.; Hassanvand, M.S.; Kashani, H.; Amini, H. Long-term exposure to ambient air pollution and autism spectrum disorder in children: A case-control study in Tehran, Iran. Sci. Total Environ. 2018, 643, 1216-1222. [CrossRef] [PubMed]

37. Gong, T.; Dalman, C.; Wicks, S.; Dal, H.; Magnusson, C.; Lundholm, C.; Almqvist, C.; Pershagen, G. Perinatal Exposure to Traffic-Related Air Pollution and Autism Spectrum Disorders. Environ. Health Perspect. 2017, 125, 119-126. [CrossRef]

38. Gong, T.; Almqvist, C.; Bölte, S.; Lichtenstein, P.; Anckarsäter, H.; Lind, T.; Lundholm, C.; Pershagen, G. Exposure to air pollution from traffic and neurodevelopmental disorders in Swedish twins. Twin Res. Hum. Genet. 2014, 17, 553-562.

39. Jung, C.-R.; Lin, Y.-T.; Hwang, B.-F. Air Pollution and Newly Diagnostic Autism Spectrum Disorders: A Population-Based Cohort Study in Taiwan. PLoS ONE 2013, 8, e75510. [CrossRef]

40. Raz, R.; Levine, H.; Pinto, O.; Broday, D.M.; Yuval; Weisskopf, M.G. Traffic-Related Air Pollution and Autism Spectrum Disorder: A Population-Based Nested Case-Control Study in Israel. Am. J. Epidemiol. 2018, 187, 717-725. [CrossRef]

41. Goodrich, A.J.; Volk, H.; Tancredi, D.J.; McConnell, R.; Lurmann, F.W.; Hansen, R.L.; Schmidt, R.J. Joint effects of prenatal air pollutant exposure and maternal folic acid supplementation on risk of autism spectrum disorder. Autism Res. 2018, 11, 69-80. [CrossRef]

42. Oudin, A.; Frondelius, K.; Haglund, N.; Källén, K.; Forsberg, B.; Gustafsson, P.; Malmqvist, E. Prenatal exposure to air pollution as a potential risk factor for autism and ADHD. Environ. Int. 2019, 133, 105149. [CrossRef]

43. Davis, E.P.; Pfaff, D. Sexually dimorphic responses to early adversity: Implications for affective problems and autism spectrum disorder. Psychoneuroendocrinology 2014, 49, 11-25. [CrossRef] [PubMed]

44. Tau, G.Z.; Peterson, B.S. Normal Development of Brain Circuits. Neuropsychopharmacology 2009, 35, 147-168. [CrossRef] [PubMed]

45. Xu, X.; Ha, S.U.; Basnet, R. A Review of Epidemiological Research on Adverse Neurological Effects of Exposure to Ambient Air Pollution. Front. Public Health 2016, 4, 157. [CrossRef]

46. Pope III, C.A.; Coleman, N.; Pond, Z.A.; Burnett, R.T. Fine particulate air pollution and human mortality: 25+ years of cohort studies. Environ. Res. 2020, 183, 108924.

47. Clifford, A.; Lang, L.; Chen, R.; Anstey, K.J.; Seaton, A. Exposure to air pollution and cognitive functioning across the life course-A systematic literature review. Environ. Res. 2016, 147, 383-398. [CrossRef]

48. Ailshire, J.; Crimmins, E.M. Fine Particulate Matter Air Pollution and Cognitive Function among Older US Adults. Am. J. Epidemiol. 2014, 180, 359-366.

49. Luyten, L.J.; Saenen, N.D.; Janssen, B.G.; Vrijens, K.; Plusquin, M.; Roels, H.A.; Debacq-Chainiaux, F.; Nawrot, T.S. Air pollution and the fetal origin of disease: A systematic review of the molecular signatures of air pollution exposure in human placenta. Environ. Res. 2018, 166, 310-323. [CrossRef]

50. Weitzman, M.; Gortmaker, S.; Sobol, A. Maternal smoking and behavior problems of children. Pediatrics 1992, 90, 342-349. [CrossRef]

51. Julvez, J.; Ribas-Fitó, N.; Torrent, M.; Forns, M.; Garcia-Esteban, R.; Sunyer, J. Maternal smoking habits and cognitive development of children at age 4 years in a population-based birth cohort. Int. J. Epidemiol. 2007, 36, 825-832. [CrossRef]

52. Miranda, M.L.; Edwards, S.E.; Keating, M.H.; Paul, C. Making the Environmental Justice Grade: The Relative Burden of Air Pollution Exposure in the United States. Int. J. Environ. Res. Public Health 2011, 8, 1755-1771. [CrossRef]

53. Briggs, D.J.; de Hoogh, C.; Gulliver, J.; Wills, J.; Elliott, P.; Kingham, S. A regression-based method for mapping traffic-related air pollution: Application and testing in four contrasting urban environments. Sci. Total Environ. 2000, 253, 151-167. [CrossRef]

54. Gilbert, N.L.; Goldberg, M.S.; Beckerman, B.; Brook, J.R.; Jerrett, M. Assessing Spatial Variability of Ambient Nitrogen Dioxide in Montréal, Canada, with a Land-Use Regression Model. J. Air Waste Manag. Assoc. 2005, 55, 1059-1063. [CrossRef] [PubMed]

55. Panico, A.; Grassi, T.; Bagordo, F.; Idolo, A.; Serio, F.; Tumolo, M.R.; De Giorgi, M.; Guido, M.; Tutino, M.; De Donno, A. Micronucleus Frequency in Exfoliated Buccal Cells of Children Living in an Industrialized Area of Apulia (Italy). Int. J. Environ. Res. Public Health 2020, 17, 1208. [CrossRef] [PubMed]

56. Villarini, M.; Levorato, S.; Salvatori, T.; Ceretti, E.; Bonetta, S.; Carducci, A.; Grassi, T.; Vannini, S.; Donato, F.; Bonetta, S.; et al. Buccal micronucleus cytome assay in primary school children: A descriptive analysis of the MAPEC_LIFE multicenter cohort study. Int. J. Hyg. Environ. Health 2018, 221, 883-892. [CrossRef] [PubMed]

57. Crews, D.; Gillette, R.; Miller-Crews, I.; Gore, A.C.; Skinner, M.K. Nature, nurture and epigenetics. Mol. Cell. Endocrinol. 2014, 398, 42-52. [CrossRef]

58. Motta, V.; Bonzini, M.; Grevendonk, L.; Iodice, S.; Bollati, V. Epigenetics applied to epidemiology: Investigating environmental factors and lifestyle influence on human health. Med. Lav. 2017, 108, 10-23.

59. Tumolo, M.R.; Panico, A.; De Donno, A.; Mincarone, P.; Leo, C.G.; Guarino, R.; Bagordo, F.; Serio, F.; Idolo, A.; Grassi, T.; et al. The expression of microRNAs and exposure to environmental contaminants related to human health: A review. Int. J. Environ. Health Res. 2020, 1-23. [CrossRef]

60. Panico, A.; Tumolo, M.R.; Leo, C.G.; De Donno, A.; Grassi, T.; Bagordo, F.; Serio, F.; Idolo, A.; De Masi, R.; Mincarone, P.; et al. The influence of lifestyle factors on miRNA expression and signal pathways: A review. Epigenomics 2020. [CrossRef] 
61. Kotsyfakis, M.; Patelarou, E. MicroRNAs as biomarkers of harmful environmental and occupational exposures: A systematic review. Biomarkers 2019, 24, 623-630.

62. Szelenberger, R.; Kacprzak, M.; Saluk-Bijak, J.; Zielinska, M.; Bijak, M. Plasma MicroRNA as a novel diagnostic. Clin. Chim. Acta 2019, 499, 98-107. [CrossRef]

63. Mandy, W.; Lai, M.-C. Annual Research Review: The role of the environment in the developmental psychopathology of autism spectrum condition. J. Child Psychol. Psychiatry 2016, 57, 271-292. [CrossRef] [PubMed]

64. Vijayakumar, N.T.; Judy, M. Autism spectrum disorders: Integration of the genome, transcriptome and the environment. J. Neurol. Sci. 2016, 364, 167-176. [CrossRef] [PubMed]

65. Yu, L.; Wu, Y.; Wu, B. Genetic architecture, epigenetic influence and environment exposure in the pathogenesis of Autism. Sci. China Life Sci. 2015, 58, 958-967. [CrossRef] [PubMed]

66. Vasu, M.M.; Sumitha, P.S.; Rahna, P.; Thanseem, I.; Anitha, A. microRNAs in Autism Spectrum Disorders. Curr. Pharm. Des. 2020, 25, 4368-4378. [CrossRef] [PubMed] 